
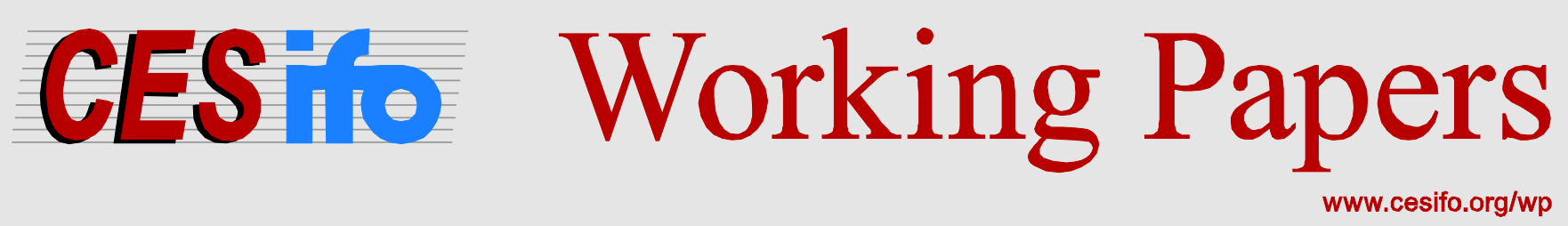

\title{
The Alma Mater Effect \\ Does Foreign Education of Political Leaders Influence Foreign Policy?
}

\author{
Axel Dreher \\ Shu Yu
}

CESIFO WORKING PAPER NO. 5871

CATEgory 2: Public CHOICE

APRIL 2016

An electronic version of the paper may be downloaded

- from the SSRN website:

- from the RePEc website:

- from the CESifo website:

WwW.SSRN.com

www.RePEc.org

www.CESifo-group.org/wp 


\title{
The Alma Mater Effect Does Foreign Education of Political Leaders Influence Foreign Policy?
}

\begin{abstract}
We study whether national leaders' foreign education influences their foreign policy, measured by voting behavior at the United Nations General Assembly (UNGA). We hypothesize that "affinity" - pre-existing or developed while studying abroad - makes leaders with foreign education more likely to vote with their host country. At the same time, such leaders need to show sufficient distance to their host country and demonstrate "allegiance" to their own one, which will reduce voting coincidence. To test this theory we make use of data on the educational background of 831 leaders and the voting affinity between the countries they govern and those in which they studied. Over the 1975-2011 period, we find that foreign-educated leaders are less likely to vote in line with their host countries but more likely to vote in line with (other) G7 countries. We identify the causal effect of "allegiance" by investigating the differential effect of foreign education on voting in pre-election years compared to other years. The difference-indifference-like results show that G7-educated leaders vote less in line with their host countries when facing an election. Overall, both "allegiance" and "affinity" affect foreign policy.
\end{abstract}

JEL-Codes: F510, F530, D780.

Keywords: United Nations General Assembly voting, foreign education, leaders.

\author{
Axel Dreher \\ Heidelberg University \\ Alfred-Weber-Institute for Economics \\ Bergheimer Strasse 58 \\ Germany - 69115 Heidelberg \\ mail@axel-dreher.de
}

\author{
Shu $\mathrm{Yu}^{*}$ \\ World Bank \\ 1818 H St NW \\ USA - Washington, DC 20433 \\ syu2@worldbank.org
}

April 8, 2016

*The views expressed in this paper are those of the author and do not necessarily represent those of the World Bank Group, its Board of Executive Directors, or the governments they represent.

We thank Chris Doucouliagos, Richard Jong-a-Pin, Julia Macdonald, and conference participants at APSA 2015 for helpful comments, and Jamie Parsons for proof-reading. 


\section{Introduction}

It is widely expected among governments and populations that educating foreign students bears important benefits for the country where they study. The economics literature shows some support: A substantial proportion of foreign students permanently stay in the country in which they studied, implying an inflow of high-skilled labor (Dreher and Poutvaara 2011). Students who return to their country of origin spread democratic values they acquired while studying in a democracy (Spilimbergo, 2009). Docquier et al. (2011) document a positive effect of emigration on the quality of political institutions in the home country in a large sample of developing countries. Micro evidence provided by Batista and Vicente (2011) shows that international migration experiences may promote better institutions at home 1

Foreign-educated students often contribute to reshaping their home country after they return. Some enter government service and some even become the political leaders of their countries ${ }^{2}$ Gift and Krcmaric (2015) show that western-educated leaders are more likely to democratize their country than other leaders. They argue that foreign education instills a sense of common identity with the international democratic community. What is more, "foreign educated leaders seem to be extremely motivated to keep up with the more developed countries where they studied" (Spilimbergo 2009: 539). Foreign-education programs like the International Lenin School aim to spread the host country's culture and ideology by producing a new stratum of leading communist party cadres (Cohen and Morgan, 2002). Elite western universities operate centers and institutes such as Yale's World Fellows Program, Harvard's Ash Center for Democratic Governance, and Oxford's Blavatnik School of Government, all aimed at grooming the next generation of global leaders.

It is commonly assumed that students would develop affinity to their host countries over the time of their studies, a feeling which will potentially have important implications for bilateral relations between the host and source country at some later point in time. However, foreign-educated leaders do not necessarily implement policies that favor their host countries. For instance, Deng Xiaoping, the leader of China from 1978 to 1992, was selected by the Chinese Communist Party to study at Moscow Sun Yat-sen University. During his tenure, Deng officially visited the United States, Japan, and Singapore, and restored China's relationship with western countries. He did little however to improve China's relationship with the Soviet Union (Marti, 2002: 19).

\footnotetext{
${ }^{1}$ Studies with similar findings include Chauvet and Mercier $(2014)$ and Pfutze $(2012)$.

${ }^{2}$ Recent studies have shown that leaders have an important impact on policy outcomes (see, e.g., Jones and Olken, 2005, Dreher et al., 2009, Besley and Reynal-Querol, 2011, and Minasyan, 2015). Dreher and Jensen (2013) show that leaders can influence foreign policy according to their preferences.
} 
Our theory-outlined in more detail in section 2 -argues that two motives are at play in shaping the voting behavior of a foreign-educated leader: "allegiance" and "affinity." Two channels drive "affinity." First, leaders studying in a particular country are likely to have selected that country for good reason, one reason being a value system they share with this country. Second, we expect students to become more familiar with the host country while living there, adopting some of the country's values. Both channels imply that countries governed by a foreign-educated leader should be more likely to vote in line with the country from which the leader acquired their education.

The second motive for foreign-educated leaders to vote with (or, rather, against) their country of study is more subtle. We argue that leaders need to signal allegiance to their home countries in order to maintain the support of their (s)electorate, by demonstrating that they are at sufficient distance from the countries where they have studied. As one example, consider Andreas Papandreou, the former Prime Minister of Greece. As a Harvard-trained academic, Papandreou was the first western prime minister to visit General Wojciech Jaruzelski in Poland and went on record in support of the Soviet Union. His antagonistic foreign policy to the United States made him popular in Greece, as the Greek population viewed the previous governments as far too loyal to the United States (Kariotis, 1992).

We argue that foreign-educated leaders vote differently from their domestically educated peers due to both the "affinity" motive and the "allegiance" motive. To test the importance of the two motives, we use data on the voting behavior of 143 countries at the United Nations General Assembly (UNGA). As we explain in more detail in Section 3 , we focus on voting over human rights, in the 1975-2011 period. This is because our theory holds for voting over issues of importance to both the G7 countries and the populations of the countries governed by the foreign-educated leaders. This is unlikely to hold for the bulk of votes in the General Assembly. However, we test our models using voting data on other dimensions, and on votes deemed to be important by the United States Department of State, in our robustness section (Section 5). We identify the causal effect of "allegiance" on voting with a difference-in-difference-like strategy, relying on the difference in the voting behavior of foreign-educated leaders to domestically educated ones at election time compared to other years. In the same framework, we further investigate the extent to which religious, political, and cultural distance between the foreign country where leaders have been educated and those that they govern change the effect of foreign education on foreign policy.

To foreshadow our results (shown in section 4), we find both "allegiance" and "affinity" to be important for how a country votes in the UNGA. On average G7-educated leaders vote less in line with their host countries but more in line with other G7 coun- 
tries. G7-educated leaders vote even less in line with their host countries when facing an upcoming election, stressing the importance of demonstrating "allegiance" at election time. When we run separate regressions for each G7 country rather than pooling them, this pre-election effect prevails regarding a country's voting with the United States, but no other G7 country. It thus seems that "allegiance" is important exclusively for leaders who have studied in the United States. Focusing on leaders who have studied there, we find the effect of foreign education to decrease with religious and cultural distance, emphasizing the particular importance of "allegiance" in countries with populations less similar to the United States.

We conclude that foreign education matters for foreign policy and discuss the implications for the educational policies of G7 countries arising from our results in section 6.

\section{Theory}

We argue that "affinity" and "allegiance" affect how countries vote in the UNGA, and discuss these motives in turn. Merriam-Webster's dictionary defines "affinity" as a "feeling of closeness and understanding that someone has ... because of their similar qualities, ideas, or interests. ' 3 It seems immediately obvious that ideas, qualities, or interests should influence students' decisions of where to study. For example, Salisbury et al. (2013) show that pre-college intercultural competence increases the likelihood that a student will study abroad. One could assume that leaders who chose to study in a country share that country's values so that they are more likely to hold a similar stance on foreign policy and therefore be more likely to vote in line with them than leaders who had studied elsewhere.

What is more, for any given value system at the time a student arrives in the host country, we expect the prolonged presence (e.g., four years for an average bachelor degree) in a country to shape a student's character, ideas, and interests. As shown in Salisbury et al. (2013), for example, studying abroad increases intercultural competence. Spilimbergo (2009) as well as Gift and Krcmaric (2015) stress the importance of foreign education in that respect, arguing that Western education instills a sense of common identity with the international democratic community. Overall, we expect that studying abroad will increase "affinity," on average.

The second key motive that we argue is crucial for how a leader votes in the UNGA is what we term "allegiance." When "allegiance" dominates, leaders with a well-known affinity to a foreign country seek to demonstrate allegiance to their (rather than their country of study's) population, in order to consolidate their popularity. Foreign-educated

\footnotetext{
${ }^{3}$ See http://www.merriam-webster.com/dictionary/affinity (date of last access: August 27, 2015).
} 
leaders' cultural affinities and extensive foreign networks (whether real or imagined) can cause a population to question their allegiance. Leaders who seek to demonstrate to the (s)electorate that their policies are aimed at benefiting their own country (rather than the country they studied in) will then be more likely to vote against their educational host country in the UNGA compared to domestically educated leaders.

We expect a leader's priority is to stay in office ${ }^{4}$ Their survival in office depends on their popularity, which in turn will be damaged by demonstrated affinity to a foreign country (by having studied there). Given that leaders' popularity matters less at nonelection time, they might well vote according to their preferences at such times. However, as elections approach, the need to demonstrate "allegiance" will increase. As one example, consider the 2008 presidential election in the Republic of China (Taiwan). Candidate Ma Yingjeo was questioned by his opponent about his possession of a U.S. permanent resident card. The fact that Ma and his wife had applied for Green Cards during his education in Harvard made voters in Taiwan question his allegiance to Taiwan. Ma's popularity seemed to suffer until he provided evidence that his card was invalid. The 2014 Malawi presidential election provides another illustrative example, with a debate on whether a Green Card holder was allowed to participate in the election at all 5 Similar debates have occurred in the United States. As the Huffington Post explains, "[w] hen he was running as the Democratic presidential challenger ... aides to then Massachusetts Senator John Kerry were concerned that their candidate who attended a Swiss boarding school as a child, learned to speak fluent French, and who spent summers at his family's estate in the coastal region of Brittany would be seen by American voters as the so-called European Candidate, or, (God forbid!) as a bit too French.' 6 More recently, critics questioned whether Canadian-born Senator Ted Cruz would be eligible to run for the U.S. presidency. This resulted in Sen. Cruz officially renouncing his dual Canadian citizenship.7

As foreign-educated leaders' exclusive commitment to their home country is less credible, it is more necessary for them to show their allegiance than for domestically educated ones. This gives foreign-educated leaders a motive to more frequently vote against their educational host countries in international fora than domestically educated leaders.

\footnotetext{
${ }^{4}$ E.g., Bueno de Mesquita et al. (2003).

${ }^{5}$ See http://www.nyasatimes.com/2014/02/06/us-clear-mutharika-on-green-card-gives-up-mp-seatcome-may-21-im-malawi-president/ (date of last access: August 27, 2015).

${ }^{6}$ See http://www.huffingtonpost.com/leon-t-hadar/john-kerry-diplomacy_b_4251473.html (date of last access: August 27, 2015).

${ }^{7}$ See http://trailblazersblog.dallasnews.com/2014/06/no-canada-sen-ted-cruz-has-formally-shed-hisdual-citizenship.html/ (date of last access: August 27, 2015). Even political figures' foreign spouses can cause controversies. Queen Maxima of the Netherlands is the daughter of Jorge Zorreguieta, the secretary of agriculture in Argentina during the National Reorganization Process dictatorship. Before the wedding, the state carried out an inquiry about Zorreguieta. To generate popularity, she addressed the nation about her engagement in Dutch, which, at the time, she barely spoke.
} 
Since questions about a candidate's allegiance draw more attention before executive elections, we expect foreign-educated leaders to send stronger signals about their allegiance to their home countries especially before elections.

We also expect that the need for leaders to show their patriotism is stronger in countries where the differences between the host country and the home country are more prevalent. Based on standard theories in international political economy (see, e.g., Oatley, 2011), important conflicts of interest are more likely between countries with different cultures and religious beliefs, and between countries with opposing political ideologies. Therefore, we expect that foreign-educated leaders will vote against G7 countries more frequently compared to their peers without foreign education especially if those countries are culturally, religiously, and politically different.

The final link in our theory regards to how leaders' preferences translate to voting in the UNGA. Dreher and Jensen (2013) and Mattes et al. (2015) show that leaders influence their countries' votes in the UNGA. We therefore expect that leaders' preferences, affected by the motives of "affinity" and "allegiance," will be directly reflected by their country's voting behavior at the UNGA.

\section{Empirical strategy}

Our empirical analysis closely follows Dreher and Jensen (2013) who study the impact of leadership change on UNGA voting. We calculate voting proximity based on UNGA voting data provided by Voeten (2013), focusing on voting affinity between G7 countries and non-industrialized countries 8

We exclude industrialized home countries as we would not expect either the "affinity" or "allegiance" motives to be sufficiently important to shape the voting behavior of these countries in the UNGA. This is because the independence of industrialized countries' foreign policies from other industrialized countries is unlikely to be of sufficient importance for leaders to change the policies of their countries (see, e.g., Oatley, 2011) 9 In the following section, we denote home countries with the index $i$, and G7 countries-the host countries-with the index $j$.

In addition to providing data on roll-call votes in the UN General Assembly, Voeten (2013) offers information on the subject of the vote. We focus on voting about human

\footnotetext{
${ }^{8}$ We do not use the ideal point estimates calculated by Bailey et al. (2015). This is because we are not interested in estimating countries' preference similarity but rather in whether or not they vote alike on any given set of votes in a particular year.

${ }^{9}$ Following Barro and Lee (2013), we coded the following countries to be industrialized (or advanced) economies: Australia, Austria, Belgium, Canada, Denmark, Germany, Finland, France, Greece, Ireland, Iceland, Italy, Japan, Luxembourg, the Netherlands, Norway, New Zealand, Portugal, Spain, Sweden, Switzerland, Turkey, United Kingdom, the United States.
} 
rights. This is because our theory applies to votes that are of importance to host and home country alike. "Affinity" is unlikely to matter for votes over technical issues or low-salience topics, but is likely to be important where values between countries differ most. If the home country populace shows no interest in a vote, the "allegiance" motive is unlikely to be important for the country's voting ${ }^{10}$ Our dependent variable thus captures the home country $i$ 's political proximity to host country $j$ on human rights issues, ranging between zero and one. The dependent variable, Vinline $_{i j t}$, is constructed following the approach of Dreher and Jensen (2013). We first code votes in agreement with the host country $j$ as 1 , votes in disagreement as 0 , and abstentions or absences as 0.5 . Then, we sum the scores obtained from all votes on human rights issues and divide it by the number of votes in a year.

We use Archigos 2.9 to identify the de facto ruler of each country. The Archigos 2.9 dataset contains information on the date and manner of entry and exit of over 3,000 de facto rulers of a state over the 1875-2004 period. We follow the guidelines of Goemans et al. (2009) and update the dataset to the end of 2011. However, controlling for the key determinants of UNGA voting patterns restricts our sample to 831 leaders from 143 non-advanced economies over the 1975-2011 period.

We collect information on the countries where leaders acquired their education before assuming office. Following Yu and Jong-A-Pin (2016), we gather data from various sources, such as Ludwig (2002) and Besley and Reynal-Querol (2011) 11 Our focus is on leaders' prior-secondary and post-secondary education, as the formation of cultural affinity, a global perspective, and transnational networks etc. are arguably not restricted to the post-secondary educational period.

\section{[Insert Figure 1 about here]}

Our key variable of interest, Foreign $E d u_{i j t}$, indicates whether the leader in country $i$ in year $t$ studied in a G7 country $j$. Figure 1 shows the distribution of leaders' education in G7 countries. In total, 33 percent of the leaders in our sample received foreign education in at least one G7 country. The United States stands out as the top destination of foreign education for the leaders in our sample (with 15 percent of the leaders having studied there), followed by the United Kingdom, and France. Less than one percent of the leaders

\footnotetext{
${ }^{10}$ We test robustness using a range of alternative topics below: Votes relating to the Palestinian conflict; to nuclear weapons and nuclear material, to arms control and disarmament, relating to colonialism; and to economic development.

${ }^{11}$ To identify who received foreign education, and where, the priority of order for the sources of our data collection is: 1) Ludwig (2002); 2) Encyclopedia Britannica; 3) individual biographies and government websites; 4) www.ruler.org; 5) Wikipedia. We compared our list of foreign-educated leaders with Besley and Reynal-Querol (2011) and double-checked those entries that differed. We also used Besley and ReynalQuerol (2011) to fill in gaps in our data set.
} 
have studied in any of the remaining four G7 countries. This distribution is likely caused by three forces. One is that leaders (or their parents) chose the destination based on the quality of higher education systems (Gift and Krcmaric, 2015). Second, many leaders from former colonies received their education in their "motherland." And third, the widespread use of English and French in the countries of origin facilitates studying in English- and French-speaking countries.

[Insert Figure 2 about here]

Figure 2 illustrates which countries have been governed by leaders with education from a G7 country. A darker color indicates that a higher percentage of the country's leaders have been educated in a G7 country. As can be seen, G7-educated leaders are densely concentrated in Africa and former colonized countries. One reason arguably is that those countries' own higher education institutes are of comparably low quality, which drives future leaders to study abroad. What is more, former colonizers, such as Great Britain and France, used to select promising young elites to study in their institutes to cultivate them to be future governors. Such examples include Paul Biya from Cameroon, Marien Ngouabi from the Republic of Congo, and Hilla Limann from Ghana.

We test the relative importance of the "allegiance" and "affinity" motives with two variants of our main explanatory variable. The first is the binary variable that indicates whether the leader from country $i$ in year $t$ studied in a G7 country $j$. Both "allegiance" and "affinity" are likely to shape the average effect of that variable on UNGA voting, so that the resulting coefficient shows their average, or the effect that dominates. In separate regressions we include a refined explanatory variable, $G \eta_{i j t}$, which equals one if the leader was educated in a G7 country other than the country with which we measure voting coincidence and zero otherwise. When voting with a G7 country where leaders have not been educated, we expect the "affinity" motive to be important to some extent, given the substantial similarity of preferences about voting on human rights in the UNGA among G7 countries. However, we expect the "allegiance" motive to be of lower importance, as there is less need to distance oneself from a country where one has not studied 12 When it comes to voting with other G7 countries, we would thus expect "affinity" to dominate "allegiance," so that the net effect of leaders with foreign education is to increase voting similarity compared to those without.

It is important to point out that a significant correlation between foreign education and voting in the UNGA does not necessarily reflect a causal effect of education. To the

\footnotetext{
${ }^{12}$ To the extent that western countries are perceived as allies it might well be that leaders are expected to demonstrate "allegiance" with respect to all G7 countries after having studied in one of them. Whether or not this indeed holds true is an empirical question that we address in our econometric framework in section 6 below.
} 
extent that countries with a greater "affinity" towards certain G7 countries are more likely to select leaders that have studied there, causality could go either way. We identify the importance of the causal effect of "allegiance" and "affinity" in a difference-in-differencelike framework. We introduce a number of variables that we argue to be important for predominantly one of the two dimensions. Specifically, we test whether foreign-educated leaders' voting behavior differs even more from that of domestically-educated leaders during election times compared to other times. The result can be interpreted as representing the difference in the effect of foreign education on voting in pre-election years compared to other years, and is thus likely to represent a causal effect rather than a mere correlation. This holds even if the effect of foreign education itself would be endogenous to voting, as long as no omitted variables are systematically correlated with differences in the leaders' voting behavior in pre-election years compared to other years 13 As "affinity" is unlikely to change in pre-election years compared to other years, we use this interaction to test the importance of the "allegiance" motive.

What is more, we interact foreign education with three other variables: the percentage of Islamic believers in a country's population; a measure of cultural distance between the home and the host country; and an indicator of political distance on the left-right scale between the home and host countries ${ }^{14}$ We tried to introduce exogenous variation by investigating the difference in the effect of these interacted variables in pre-election years compared to other years. However, none of these triple-interactions turns out to be significant. As Dreher et al. (2016) explain, the differential effects of these distance measures on voting can still be interpreted as causal, to the extent that any channel by which distance affects voting is independent of whether or not the leader has received foreign education.

To study voting affinity between a non-industrialized economy and each G7 country, we analyze a pooled time-series cross-section sample. The analysis covers the 19752011 period and extends to a maximum of 143 countries, limited by the availability of data. The resulting regression model is structured as follows:

$$
\text { Vinline }_{i j t}=\alpha_{0}+\pi_{\mathbf{t}}+\pi_{\mathbf{i}}+\beta \text { Foreign Edu } u_{i j t}+\gamma \mathbf{X}_{\mathbf{i j t}(-\mathbf{1})}+\epsilon_{i j t}
$$

where the dependent variable Vinline $_{i j t}$ is voting coincidence between country $i$ (home)

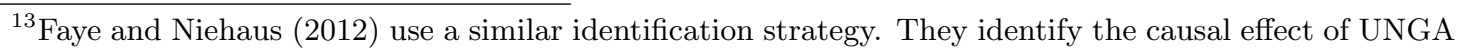
voting similarities between donors and recipients on the amount of foreign aid given comparing election years to other times. Nizalova and Murtazashvili (2016) and Bun and Harrison (2014) provide the econometric background. Also see Appendix F in Dreher et al. (2016).

${ }^{14}$ We take Islam from Maoz and Henderson (2013) and CulturalDistance from Wacziarg and Spolaore (2015). It is based on data from the World Values Survey and measures the difference on 98 values-related survey questions across 74 countries. Political ideology is from Beck et al. (2001), as we describe in more detail below.
} 
and country $j$ (host) in year $t$. We include year dummies $\pi_{\mathbf{t}}$ and home country fixed effects $\pi_{\mathbf{i}}$ in all regressions. Foreign Edu $u_{i j t}$ is our variable of interest while $\mathbf{X}_{\mathbf{i j t}(-\mathbf{1})}$ is a vector of control variables. The control variables include leaders' educational attainment and common determinants of UNGA voting, following Dreher and Jensen (2013). We use lagged values of time-varying control variables to reduce potential simultaneity.

More specifically, Dreher and Jensen (2013) show that when the respective country's government has the same political orientation (i.e., both left or both right) UNGA voting in line with the United States is higher 15 Therefore, we construct a dummy variable (Political color inline $_{i j t-1}$ ) indicating that country $i$ 's government has the same political color as the government of a G7 country $j$ (i.e., both left and both right). The data are provided by Beck et al. (2001) (DPI, updated in Jan. 2013) and are available from the year 1975 .

We control for GDP per capita, GDP growth, and higher imports from a G7 country to the respective country, measured as a share of recipient country $i$ 's GDP, using data from UN Comtrade (2013). Dreher and Sturm (2012) suggest GDP per capita and GDP growth as proxies for dependence, expecting weaker countries to vote more in line with the G7. Imports are included based on Kim and Russett (1996), who expect that stronger economic ties with developed countries create feelings of exploitation, making them vote less in line with their trading partners. GDP per capita and GDP growth are taken from the World Development Indicators (WDI). In line with Dreher and Jensen (2013), we include aid commitments from $G 7_{j}$ (as a share of recipient country $i$ 's GDP), provided by the OECD DAC (2013) as an additional route by which a G7 country could change the recipient's voting behavior, so that voting similarity increases with aid 16

As suggested by Gift and Krcmaric (2015), leaders went abroad in particular to acquire higher (rather than primary or secondary) education. We expect that higher education will make leaders more able to design independent foreign policies and vote differently from less educated leaders. To make sure that our results are not driven by higher education rather than foreign education, we control for leaders' educational attainment before assuming office, Education. The numerical variable is taken from Yu (2015) and ranges from zero to seven. Similar to Besley and Reynal-Querol (2011) and $\mathrm{Yu}$ and Jong-A-Pin (2016), Yu (2015) classifies leaders' educational attainment into the following

\footnotetext{
${ }^{15}$ Potrafke (2009a) provides an interesting analysis of the role of a government's ideology on UNGA voting. According to his results, left-wing governments systematically vote less in line with the United States. This effect is stronger when the U.S. President is Republican. The ideology index employed there (taken from Potrafke, 2009b) cannot be used in our analysis as it is only available for OECD countries. The same holds for the index developed in Bjørnskov (2008).

${ }^{16}$ We do not control for corruption as this substantially reduces the size of our sample. For our main results, the sample size shrinks from 28,663 to 17,904 . The results do not change when we control for corruption. Detailed results are available on request.
} 
eight categories: 1) illiterate (no formal education); 2) literate (no formal education); 3) elementary/primary school education or tutors; 4) high/finishing/secondary/trade school; 5) special training (beyond high school, such as mechanical, nursing, art, music, or military training), 17 6) college-educated; 7) qualifications from a graduate or professional school (e.g., master's degree); and 8) doctorates (e.g., Ph.D.). Education has a value of zero when the leader is illiterate, and seven when the leader holds a Ph.D. We provide detailed information on the data sources and descriptive statistics of all variables in Table A.1 in the Appendix.

\section{Empirical results}

Table1 1 investigates the effect of foreign education on voting coincidence with G7 countries. Voting is at the host-source-country and year level, including fixed effects for each sourcecountry and year (see equation (1) above). Across most of the regressions, control variables show significant coefficients. The results show that countries governed by parties of the same political color are more likely to vote in line with each other. It thus seems that the similarity of political preferences between these parties also transmit to foreign policy. Voting coincidence with the host G7 country increases with per capita GDP, and decreases with GDP growth. As expected, we also find that better educated leaders have a higher probability of voting in line with the average G7 country. When we do not control for host country-fixed effects in columns (1)-(3), voting coincidence decreases with a country's share of imports from the G7 in its GDP, while the amount of aid received is not significant at conventional levels. Including these fixed effects (columns (4) and (5)) imports lose their significance, while voting coincidence between donors and recipients increases with the amount of aid disbursed. Dreher and Sturm (2012) suggest GDP per capita and GDP growth as well as aid as proxies for dependence, expecting more dependent countries to vote more in line with the G7. While these expectations receive support from the negative effect of growth and-in columns (4) and (5)-the positive effect of aid, it seems that the effect arising from the similar preferences of countries with a comparable level of GDP dominate the dependency effect in our sample. The negative effect of imports on voting similarity in columns (1)-(3) is in line with Kim and Russett (1996) who argue that strong economic ties with developed countries can create feelings of exploitation, which could make them vote against their trading partners.

Turning to our variable of interest-foreign education-column (1) shows the effect of leaders' education in any G7 country on their voting coincidence with the average G7

\footnotetext{
${ }^{17}$ Military training programs that do not result in the attainment of a bachelor degree fall in this category. These programs normally issue a certificate rather than a degree after completion. Military academy graduates are counted as college graduates.
} 
country. The resulting coefficient shows the average effect of "allegiance" and "affinity." Column (2) focuses on the effect of education in a particular G7 country on voting coincidence with that country, while column (3) tests whether leaders who were educated in a G7 country other than country $j$ will vote more or less in line with country $j$. Column (2) thus also tests the combined effect of leaders' "allegiance" and "affinity" motives; column (3) is more likely to measure "affinity." This is because values and culture are to some extent similar across G7 countries, while there is no reason to demonstrate "allegiance" by voting against a G7 country that one has not lived and studied in 18

As can be seen, voting coincidence is not significantly affected by education in any G7 country, on average (column (1)). The insignificant coefficient reflects the average of a significantly negative coefficient for studying in the same country (column (2)) and a significantly positive one for having studied in another G7 country (column (3)). Specifically, leaders who have studied in a G7 country are 0.04 percentage points less likely to vote in line with the country that hosted their study, while they vote more in line with another G7 country by 0.02 percentage points (both at the one percent level of significance). This indicates that the "allegiance" motive dominates the "affinity" motive when it comes to voting in line with a country where the leader studied, while the "affinity" motive dominates voting behavior with respect to other G7 countries. These results fit our theory well.

\section{[Insert Table 1 about here]}

Columns (4) and (5) investigate differential effects across G7 countries. We therefore include binary indicator variables for each G7 country (but do not show them in the table to reduce clutter), omitting Canada as a reference category. Our variables of interest are interactions of these dummies with the indicator variable for foreign education. As can be seen, there are substantial differences across voting coincidence with G7 countries. The results of column (4) show that countries with leaders who have been educated in Germany, Italy, and Japan are more likely to vote in line with their leaders' host country compared to countries with leaders educated in Canada. Compared to Canada (with a negative, insignificant coefficient), countries with leaders that have been educated in Germany are 0.06 percentage points more likely to vote in line with Germany in the UNGA, at the ten percent level of significance. At the five percent level at least, the corresponding increases are 0.08 percentage points for Italy, and 0.12 percentage points for Japan. According to column (5), countries with leaders that have been educated in other G7 countries are less likely to vote in line with the United States, compared to Canada, and more likely to vote in line with the United Kingdom, both at the ten percent level of significance.

\footnotetext{
${ }^{18}$ This is unless voting similarity with one G7 country proxies for voting with other G7 countries also. We return to this below.
} 
Table 2 explores the effect of elections, culture, political color, and religion on how foreign education affects voting behavior in the UNGA. While columns (1)-(4) focus on how foreign education affects voting with the country in which the education was acquired, columns (5)-(8) test the effect of education in other G7 countries. More specifically, we include a binary indicator Pre - election, which equals one when the leader is facing an executive election in the next year and zero otherwise (obtained from Beck et al., 2001). We do not focus on election years themselves, as six months in such years will be after, rather than before elections, on average. We include interactions of foreign education with Islam, which measures the percentage of Islamic believers in a country's population, and CulturalDistance. Islam is also included in levels, while CulturalDistance does not vary over time and is thus captured by the recipient country fixed effects.

\section{[Insert Table 2 about here]}

As can be seen from Table 2, the effect of foreign education on voting similarity with the host country decreases prior to elections, at the one percent level of significance. This result can be interpreted as representing the difference in the effect of foreign education on voting in Pre-election years compared to other years, and thus represents a causal effect rather than a mere correlation. This holds even if the effect of foreign education itself is endogenous to voting, as long as no omitted variables are systematically correlated with differences in the leaders' voting behavior in pre-election compared to other years. As there is no reason for "affinity" to change in pre-election years compared to other years, we take this result as evidence of the importance of the "allegiance" motive. We do not find a comparable effect of elections for countries governed by leaders with education in other G7 countries (column (5)), further corroborating this interpretation. While voting in line with the host country potentially induces suspicions about "allegiance," it is apparently less costly for foreign-educated leaders to reveal their "affinity" when voting with G7 countries the leader has not studied in.

The results also show that the effect of foreign education depends on neither religion, nor cultural distance. The same holds for political color, that we also introduce as an interaction (in columns (4) and (8)). We also introduced a triple-interaction term between any of these variables and the Pre-election variable, testing whether differences between the host and home country of a leader turn significant at times when "allegiance" arguably matters most. While we do not show these results in a table, it should be noted that none of these triple interactions are significant at conventional levels.

$$
\text { [Insert Table } 3 \text { about here] }
$$

As shown in column (4) of Table 1, the impact of foreign education on UNGA voting patterns differs among host countries. In Table 3, we therefore split the sample 
and investigate the effect of foreign education on voting in line with the host country for one G7 country at a time. The results are similar to those in Table 1 above. As can be seen, countries with leaders who have received education in Germany, Italy, and Japan are more likely to vote in line with these countries in the UNGA, with marginal effects ranging between 0.04 (Germany and Japan) and 0.08 (Italy) percentage points. The results are similar for the United States, but weaker in magnitude and statistical significance, with a marginal effect of 0.02 , significant at the ten percent level.

\section{[Insert Table 4 about here]}

Table 4 focuses on the United States-the country that hosted the largest number of foreign-educated leaders among the group of countries where we found significant average effects of foreign education-and again examines differential effects of foreign education (in line with Table 22.19 The results in column (1) show that U.S.-educated leaders are less likely to vote in line with the United States in pre-election years. Again, this result can be interpreted as a difference-in-difference and represents a causal effect rather than a mere correlation. Again, the result is in line with our "allegiance" hypothesis.

According to column (2), foreign-educated leaders governing a country with a high percentage of Islamic believers are less likely to vote in line with the United States, as one would expect. Figure 3 shows the marginal effect of U.S.-education on UNGA voting in line with the United States for different levels of the percentage of Islamic believers in a country's population, in tandem with the 95 percent confidence interval. As can be seen, the marginal effect decreases with the percentage of Islamic believers. Specifically, U.S.-educated leaders vote more line with the United States than other leaders unless the percentage of Islamic believers in their population exceeds 20 percent, above which U.S.-education is no longer significant at conventional levels.

[Insert Figure 3 about here]

Column (3) turns to cultural distance. As can be seen-in a much-reduced sample due to data availability-the effect of foreign education on voting similarity decreases with cultural distance. Figure 4 shows the marginal effect of foreign education in the United States on voting similarity for different values of cultural distance. In line with our theory, the marginal effect decreases with distance. The effect of U.S.-education is significantly positive unless cultural distance from the United States exceeds -40 (on a -62 to 100 scale), is insignificant for intermediate values, and turns significantly negative when a country's

\footnotetext{
${ }^{19}$ We also estimated these regressions for France and the United Kingdom and found few significant interactions. Specifically, Foreign Education*Cultural Distance is marginally significant, while the other interactions are not significant at conventional levels.
} 
cultural distance from the United States exceeds 30. In other words, for high values of cultural distance, U.S.-educated leaders vote less in line with the United States than leaders without a U.S. education.

\section{[Insert Figure 4 about here]}

In addition, we find that PoliticalColor does not significantly affect the effect of foreign education. These results hold when we include the interactions jointly rather than separately (in column 5), where we exclude cultural distance to preserve the size of the sample 20

\section{[Insert Table 5 about here]}

Table 5 sheds further light on the motives underlying differential voting of foreigneducated leaders. If "affinity" drives the result, we would expect religion and cultural distance to also affect how leaders vote in the UNGA when they have been educated in other G7 countries. We therefore replicate the analysis of Table 4 but focus on how foreign education in a G7 country other than the United States affects voting similarity with the United States. We again expect "affinity" with Western values to affect voting behavior, while the need to show some distance to the United States and demonstrate "allegiance" will arguably be less relevant for political leaders who have studied in a G7 country other than the United States. Table 5 shows this to be the case. Of the three significant and negative interaction effects shown in Table 4 , the interaction with Pre-Election and Islam are no longer significant at conventional levels. The interaction with CulturalDistance stays significant at the five percent level, but the coefficient has switched its sign. In line with our theory, we now find that the effect of foreign education increases with CulturalDistance, arguably indicating that the effect of acquiring "affinity" through foreign education can be particularly strong if the distance between the home and host countries are large (which will on average also imply a larger pre-education distance between the student leaderto-be and their host-country's population) ${ }^{21}$ We again also interact all interactions with Pre-election, to test whether and to what extent the effect of distance on voting increases at election time. It turns out that all triple-interactions are insignificant at conventional levels (not shown in the table).

The next section tests the robustness of our main results.

\footnotetext{
${ }^{20}$ We replicated the regression in column 5 including cultural distance as well. While the results hardly change, this reduces the sample size to 1204, which is less than one third of the full sample. In this regression, the interaction between U.S. education and the pre-election year dummy stays significant and negative while the other interactions maintain their sign but are not significant at conventional levels.

${ }^{21}$ We do again not include all interactions in one regression, as this would reduce the sample size to about one third of the full sample.
} 


\section{$5 \quad$ Tests for robustness}

We test the robustness of our main results along a number of important dimensions. First, we test whether foreign education affects voting affinity in the years before or after a preelection year. As significant interaction effects in these years could not be explained by our theory, we consider their inclusion an important placebo test. Second, we include the average voting affinity of a country with a foreign-educated leader with all other G7 countries. Voting across G7 countries might be so similar that it is less likely for us to find supporting evidence for our theory when focusing on voting with one of them without controlling for the others. Third, we gauge the importance of omitted variable bias following the approach of Altonji et al. (2005) and Bellow and Miguel (2009). Specifically, we compare the relative impact that unobserved variables would need to have on our coefficients of interest to observed ones. Finally, we extend the scope of our analysis by investigating voting affinity across a number of different dimensions.

Column (1) of Table 6 includes a binary indicator that takes a value of one two years before an election (i.e., Pre-election $t_{t-1}$ ) and its interaction with foreign education, focusing on the dyadic sample that includes all host countries. As can be seen, voting coincidence of countries with foreign-educated leaders two years before an election is higher as well, by a magnitude similar to those of pre-election years. The interaction with foreign education is however not significant at conventional levels, in contrast to the interaction with the pre-election year dummy, which is significant at the one percent level. The insignificant placebo variable lends further credibility to our interpretation of the results.

In column (2), we add an indicator for the election year itself (and its interaction with foreign education); columns (3) and (4) replicate the regressions focusing on voting with the United States and U.S.-based education exclusively. The results show that none of the additional interactions is significant at conventional levels. This holds if we add further leads and lags to these regressions (though the significance of the interaction between U.S. education and Pre-election is weaker in these regressions).

[Insert Table 6 about here]

Table 7 controls for average voting of other G7 countries. Column (1) again shows results from the dyadic setup including all G7 countries, while columns (2)-(5) focus on the United States exclusively. In line with the previous results, countries with a foreigneducated leader vote less in line with G7 countries in election years. Column (3) shows that the same holds for the United States, while the average effect of having studied in the United States on voting coincidence is no longer significant (column 2). Column 4 shows that the effect of U.S.-education on voting with the United States remains larger with a higher percentage of Islamic believers in the population even when we control for average 
voting with the other G7 countries. This result is thus peculiar to voting with the United States, rather than being driven by voting in line with western countries more broadly. The same does not hold for the effect of cultural distance as shown in column (5).

[Insert Table 7 about here]

We next turn to the importance of omitted variable bias. Foreign education and UN voting patterns may be jointly driven by leaders' unobserved personal characteristics. It is possible that leaders choose to study in a foreign country because they share some unobserved values or ideology with the host country population, but there is no way for us to control for this. To test the importance of such omitted leader characteristics on our main results, we follow Altonji et al. (2005) and Bellow and Miguel (2009) and gauge how important omitted variable bias would have to be relative to the influence of observables in order for our result to vanish. Altonji et al. (2005) assume that the set of observed control variables is chosen randomly from the full set of controls that could influence the results ${ }^{22}$ In order to assess the relative importance of unobserved leader heterogeneity, we gathered information on their observed personal characteristics: 1) Age, 2) an indicator for being a Woman, and 3) Profession 23 Specifically, we distinguish five professions that leaders may have assumed prior to taking office: lawyers, businessmen, civil servants, scientists, and military officers. We also include an indicator variable for leaders who belong to the royal family or are related to a former leader via bloodline or marriage.

Table A.2 in the Appendix tests the robustness of our results to the inclusion of these leader characteristics. The results show that countries with older leaders tend to vote less in line with G7 countries in the General Assembly. The same holds for countries governed by former military officers, while voting coincidence of countries governed by former lawyers and businessmen is higher. This also holds for members of the royal family, with a coefficient that is however only marginally significant. When it comes to voting with the United States, voting coincidence of countries governed by former lawyers is higher, while it is lower for those governed by women.

Comparing the coefficients of interest in the models with and without the additional control variables it can be seen that most of them hardly change with the inclusion of the additional explanatory variables. With the exception of the interaction of foreign education with the host country-dummies (shown in columns (7) and (8) of Table A.2), the coefficients of interest are very similar across models. It thus seems that observed

\footnotetext{
${ }^{22}$ As Altonji et al. (2005) point out, this assumption is not more restrictive than the typical OLS assumptions. They also assume that the number of observed and unobserved variables is large enough for none of them to dominate the distribution of the variables of interest.

${ }^{23}$ Information on leaders' age is obtained from Archigos 2.9; those on gender and profession follows $\mathrm{Yu}$ and Jong-A-Pin (2016) and is gathered from various sources, such as Ludwig (2002) and Besley and Reynal-Querol (2011). Detailed information can be found in section 3.
} 
leader heterogeneity hardly influences our results. To gauge the importance of unobserved heterogeneity, we further follow Altonji et al. (2005) and Bellow and Miguel (2009) and calculate the influence omitted variables would need to have relative to the observed control variables to fully account for our results. A large ratio suggests that it is unlikely that omitted variable bias could invalidate the results found for the variable of interest 24 In other words, if the inclusion of additional controls substantially changes the coefficient estimates on Foreign Eduction or our interacted variables, the estimated effect could well diminish when further controls are added. To the extent that the inclusion of additional controls does not affect the coefficients of these variables, our findings are more likely to imply a causal impact of the leaders' foreign education background on UN voting patterns.

Following Bellow and Miguel (2009), we estimate the importance that omitted variables would need to have relative to those of the observed variables in order to explain away the entire effect of our variables of interest. For instance, the (absolute) estimated effect of foreign education on voting in line with the host country is 0.041 according to column 3 of Table A.2. Column 4 shows that the coefficient increases to 0.044 when we control for observed leader heterogeneity. This suggests that omitted variable bias would need to be almost 14 times larger (i.e., 0.041/(0.044-0.041))-and in the opposite direction-than the impact of the observed variables to explain away the entire effect of Foreign Eduction. We consider this unlikely 25 The ratios for most of our models are clearly above 3, with the exception of the more fragile results for the host country interactions shown except columns (7)-(8), where the ratio is below 1 . We conclude that our main results are unlikely to be fully explained by omitted variables bias.

Finally, we replicate the main regressions for different dimensions of voting in the General Assembly. While we prefer to investigate voting on human rights for the reasons outlined above, this does not preclude that we might find similar results for other dimensions. Table 8 summarizes the results of these regressions. Column (1) uses voting similarity calculated from all voting topics in the UNGA rather than those on human rights exclusively, while column (2) focuses on voting topics that are identified as "key" to the national interests of the United States by the U.S. Department of State. These are votes where the Department of State explicitly states that it tried to influence the outcome. Columns (3) to (7) cover voting on one specific topic each: (3) votes relating to nuclear weapons and nuclear material, (4) arms control and disarmament, (5) the Palestinian conflict, (6) colonialism, and (7) economic development.

\footnotetext{
${ }^{24}$ The ratio can be expressed as $\frac{a_{o \hat{l} s, c}}{a_{o l s}, n c-a_{o \hat{l} s, c}}$ where $a_{o \hat{o l s}, n c}$ is the estimated coefficient without additional controls while $a_{o \hat{l} s, c}$ is the estimated coefficient with additional controls. The Online Appendix of Bellow and Miguel (2009) provides details.

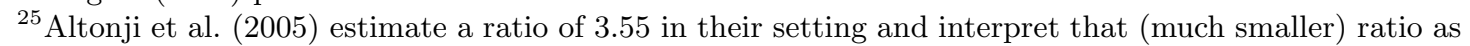
evidence that unobservables are unlikely to explain away the entire effect of their variable of interest.
} 
Table 8 reports the coefficients of interest exclusively. These estimates are based on analogous regressions to those above, including the full set of control variables and respective fixed effects. In the dyadic estimates (in line with those in column (1) of Table 1), we find that the effect of foreign education on voting similarity with the host country decreases in pre-election years at the one percent level of significance in all seven regressions, much in line with our previous finding for voting on human rights above.

The further rows in Table 8 refer to voting similarity with the United States instead. As can be seen (in regressions following those of column (1) in Table 3 above), education in the United States does not significantly affect any of these additional voting dimensions, the exception being votes on economic development, where the effect turns negative rather than positive. The interactions of U.S.-education with Pre-election (following the regression of column (1) in Table 4 above) is negative and significant in four of the seven regressions; those with the share of Islamic believers in population in two, while the interaction with cultural distance is significant and positive in one of the regressions and not significant at conventional levels in the others.

Overall, foreign-educated leaders tend to vote against their host countries on votes relating to colonialism which is a predominant source of conflict among former colonizers and their former colonies (Oatley, 2011). The negative effect of foreign education is least prevalent for key votes, where votes "directly affected the U.S. interests and on which the United States lobbied extensively" (U.S. Department of State, 2008; p.123). When voting against host countries on issues that are essential to them, foreign-educated leaders run the risk of losing aid and other kinds of support in the future. Since such support could be crucial to their survival in office, it is more costly to vote against their host countries on votes that are important to them (but not necessarily to the home country as well). This suggests that foreign-educated leaders would show their allegiance in a way that is less costly and more effective to their populations.

In summary, we conclude that our main results for voting on human rights-related topics in the UNGA are robust to controlling for average voting affinity of a country with a foreign-educated leader with all other G7 countries. Our findings are unlikely to be driven by omitted variables bias. We find insignificant interactions between foreign education and voting alignment in years other than pre-election years, which we consider an important placebo test. We find similar results for other dimensions regarding the effect of foreign education on voting in pre-election years across a number of topics in the UNGA (but not for our other results). 


\section{Conclusion}

We hypothesized that "affinity" and "allegiance" are important motives facing leaders when deciding their countries' foreign policy. On the one hand, leaders educated in a foreign country are more likely to pursue friendly policies with respect to their former host country. This is likely due to their having shared ideas and values before deciding to study in a given host country already. What is more, having lived in the country is likely to have further contributed in establishing understanding and respect for the host country's position on foreign policy. Overall, their "affinity" for their host country could drive them to align themselves with their hosts when in office. On the other hand, we argued that leaders with some foreign education will raise suspicions with their populations with regards to their loyalties. In order to demonstrate "allegiance" with their own country and assuage these doubts, we expect them to distance themselves from the foreign policies of their former host.

Using data on countries' voting behavior at the United Nations General Assembly (UNGA) on human rights issues over the 1975-2011 period, we found that foreign-educated leaders are less likely to vote in line with their host countries and are more likely to vote in line with other G7 countries. We interpret this as evidence for the relative roles that the "affinity" and "allegiance" motives play. We further identified the causal effect of "allegiance" by investigating the differential effect of foreign education on voting in preelection years compared to other years. The difference-in-difference-like results showed that G7-educated leaders vote less in line with their host countries when facing an election.

We find the effect of foreign education on voting with other G7 countries but not on voting with the host country to be affected by the percentage of Islamic believers in the population. The probability to vote with other G7 countries decreases with the share of Islamic believers, while the probability of voting in line with the host country is unaffected. While it seems that foreign-educated leaders of countries with a significant Islamic population thus do not need to show their "allegiance," leaders of Islamic countries seem less likely to develop "affinity" to the values of G7 countries while being educated in one of these countries, on average. When we focus on voting with the United States exclusively, the main results are similar. We find that when a leader governs a country with a larger share of Islamic believers or a greater cultural distance to the host then the effect of foreign education decreases. It seems that in such countries the "affinity" motive is less likely to have an effect on foreign policy.

Our results bear at least three important implications for educational policy. First, there seem to be differences in how foreign education shapes "affinity" depending on the country where leaders have studied. Second, education policy can be more effective with respect to students from countries that are culturally distant (at least in the case of the 
United States). And third, while educating future leaders indeed fosters a certain degree of "affinity," on average, "affinity" cannot be taken for granted and will be less forthcoming at times the leaders face election at home. We suspect that in order to alleviate the negative effect of "allegiance" on voting with the host country, larger shares of population would need to receive "affinity" -building foreign education. To what extent foreign education can be used to increase "affinity" among the home-country population more broadly is an interesting question that we leave for future research to address.

\section{References}

Altonji, J. G., T. E. Elder, and C. R. Tabe (2006). Selection on observed and unobserved variables: Assessing the effectiveness of Catholic schools. Journal of Political Economy 113(1), 151-184.

Anderson, T., T. Harr, and F. Tarp (2006). On US politics and IMF lending. European Economic Review 50, 1843-1862.

Bailey, M., A. Strezhnev, and E. Voeten. (2015). Estimating dynamic state preferences from UN voting data. Journal of Conflict Resolution, forthcoming.

Barro, R. and J. Lee (2013). A new data set of educational attainment in the world, 1950-2010. Journal of Development Economics 104, 184-198.

Batisa, C. and P. Vincente (2011). Do migrants improve governance at home? Evidence from a voting experiment. World Bank Economic Review 25(1), 77-104.

Beck, T., G. Clarke, A. Groff, P. Keefer and P. Walsh (2001). New tools and new tests in comparative political economy: the Database of Political Institutions. World Bank Economic Review 15(2), 165-176.

Bellow, J. and E. Miguel (2009). War and local collective action in Sierra Leone. Journal of Public Economics 93, 1144-1157.

Besley, T. and M. Reynal-Querol (2011). Do democracies select more educated leaders? American Political Science Review 105 (03), 552-566.

Bjørnskov, C. (2008). Political ideology and the structure of national accounts in the Nordic countries, 1950-2004. Paper presented at the annual meeting of the European Public Choice Society, Jena.

Bun, M. and T. Harrison (2014). OLS and IV estimation of regression models including endogenous interaction terms. University of Amsterdam discussion paper No. 2014-02. 
Bueno de Mesquita, B., A. Smith, R. Siverson and J. Morrow (2003). The Logic of Political Survival. MIT, Cambridge.

Chauvet, L. and M. Mercier (2014). Do return migrants transfer political norms to their origin country? Evidence from Mali. Journal of Comparative Economics. 42 (03), 630-651.

Docquier, F., E. Lodigiani, H. Rapoport, and M. Schiff. (2011). Emigration and democracy. Centro Studi Luca d'Agliano Development Studies Working Paper $30 \%$.

Cohen, G., and K. Morgan. (2002). Stalin's Sausage Machine. British Students at the International Lenin School, 1926-37. Twentieth Century British History 13 (4), 327355.

Dreher, A., V. Eichenauer, and K. Gehring (2016). Geopolitics, Aid and Growth: The Impact of UN Security Council Membership on the Effectiveness of Aid. Heidelberg University.

Dreher, A. and N. M. Jensen (2013). Country or leader? Political change and UN General Assembly voting. European Journal of Political Economy 29, 183-196.

Dreher, A., M. Lamla, S. Lein, and F. Somogyi (2009). The impact of political leaders' profession and education on reforms. Journal of Comparative Economics 37(1), 169-193.

Dreher, A. and P. Poutvaara (2011). Foreign Students and Migration to the United States. World Development 38, 1294-1307.

Dreher, A. and J.-E. Sturm (2012). Do the IMF and the World Bank influence voting in the UN General Assembly? Public Choice 151(1), 363-397.

Faye, M. and P. Niehaus (2012). Political Aid Cycles. American Economic Review 102(7), $3516-3530$.

Gift, T. and D. Krcmaric (2015). Who Democratizes? Western-educated Leaders and Regime Transitions. Journal of Conflict Resolution, forthcoming.

Goemans, H. E., K. S. Gleditsch, and G. Chiozza. (2009). Introducing Archigos: A dataset of political leaders. Journal of Peace Research 46 (2), 269-283.

Jones, B. and B. Olken (2005). Do leaders matter? National leadership and growth since World War II. Quarterly Journal of Economics 120(3), 835-864.

Kariotis, T. (1992). The Greek Socialist Experiment: Papandreou's Greece 1981-1989. Pella Pub Co. 
Kim, S.Y. and B. Russett (1996). The new politics of voting alignment in the United Nations General Assembly. International Organization 50(4), 629-652.

Ludwig, A. M. (2002). King of the Mountain: The nature of political leadership. Lexington, KY: University Press of Kentucky.

Maoz, Z. and E. A. Henderson (2013). The world religion dataset, 1945-2010: Logic, estimates, and trends. International Interactions 39(3), 265-291.

Marti, M. (2002). China and the legacy of Deng Xiaoping: From communist revolution to capitalist evolution. Potomac Books.

Mattes, M., B. A. Leeds, and R. Carroll. (2015). Leadership turnover and foreign policy change: Societal interests, domestic institutions, and voting in the United Nations. International Studies Quarterly 59 (2), 280-290.

Minasyan, A. (2015). Your development or mine? Effects of donor-recipient cultural differences on the aid-growth nexus. Journal of Comparative Economics.

Nizalova, O. and I. Murtazashvili (2016). Exogenous treatment and endogenous factors: vanishing of omitted variable bias on the interaction term. Journal of Econometric Methods 5(1), 71-77.

Oatley, T. (2011). International Political Economy (5th Editon). Pearson.

OECD DAC (2013). Development Assistance Committee database. http://www.oecd.org/dac/aidstatistics/.

Pfutze, T. (2012). Does migration promote democratization? Evidence from the Mexican transition. Journal of Comparative Economics 40(2), 159-175.

Potrafke, N. (2009a). Does government ideology influence political alignment with the US? An empirical analysis of voting in the UN General Assembly. Review of International Organizations 4, 245-268.

Potrafke, N. (2009b). Did globalization restrict partisan politics? An empirical evaluation of social expenditures in a panel of OECD countries. Public Choice 140, 105-124.

Salisbury, M. H., B. P. An, and E-T. Pascarella (2013). The Effect of Study Abroad on Intercultural Competence Among Undergraduate College Students. Journal of Student Affairs Research and Practice 50 (1), 1-20.

Spilimbergo, A. (2009). Democracy and Foreign Education American Economic Review 99, $528-543$. 
Thacker, S. (1999). The high politics of IMF lending. World Politics 52, 38-75.

Voeten, E. (2013). Data and Analyses of Voting in the UN General Assembly. Routledge Handbook of International Organization edited by Bob Reinalda, Routledge, 54-66.

UN Comtrade (2013). http://unstats.un.org/unsd/tradekb/Knowledgebase/.

Spolaore, E. and R. Wacziarg (2015). Ancestry, language and Culture The Palgrave Handbook of Economics and Language. Edited by V. Ginsburgh and S. Weber, London: Palgrave Macmillane, Chapter 7.

Yu, S. and R. Jong-A-Pin (2016). Political Leader Survival: Does Competence Matter? Public Choice, forthcoming.

Yu, S. (2015). Political Instability and Leader Selection. Working paper. 
Figure 1: Leaders' Education in G7 Countries

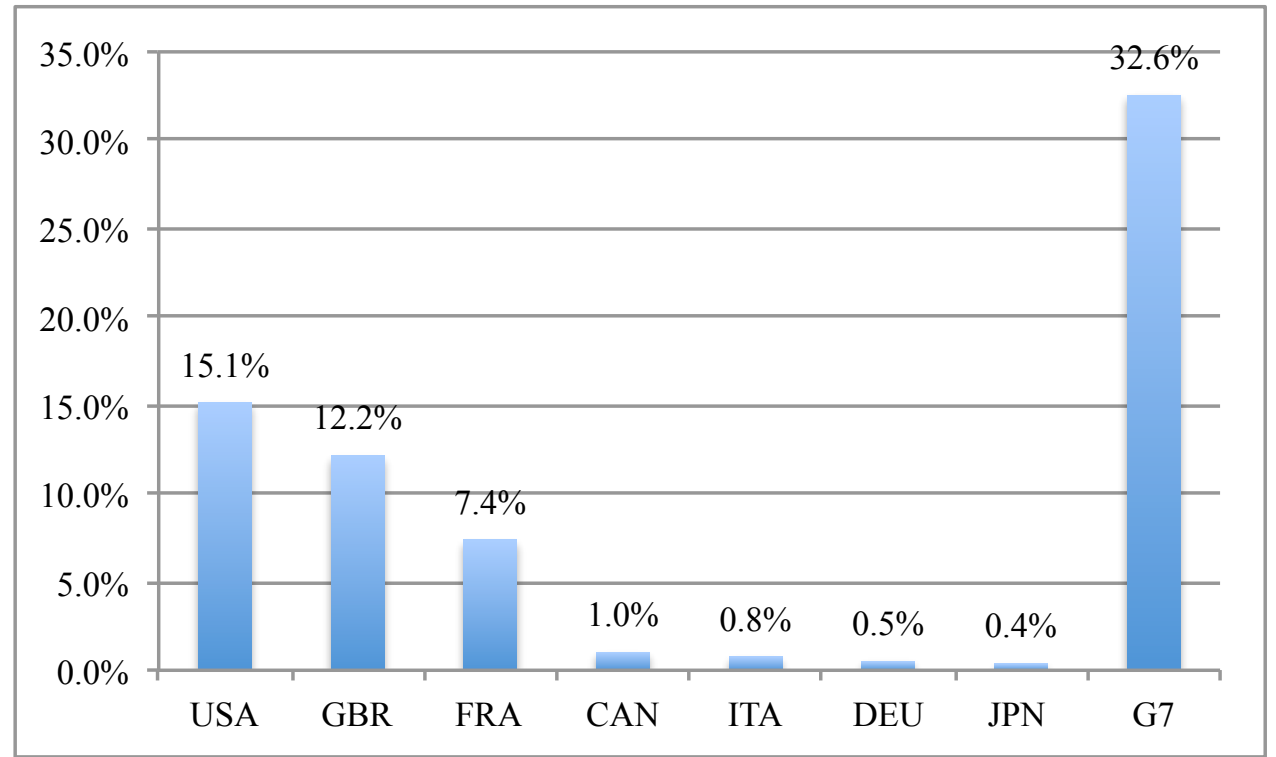

Notes: Figure 1 shows the percentage of leaders in our sample that received education from a respective G7 country. 


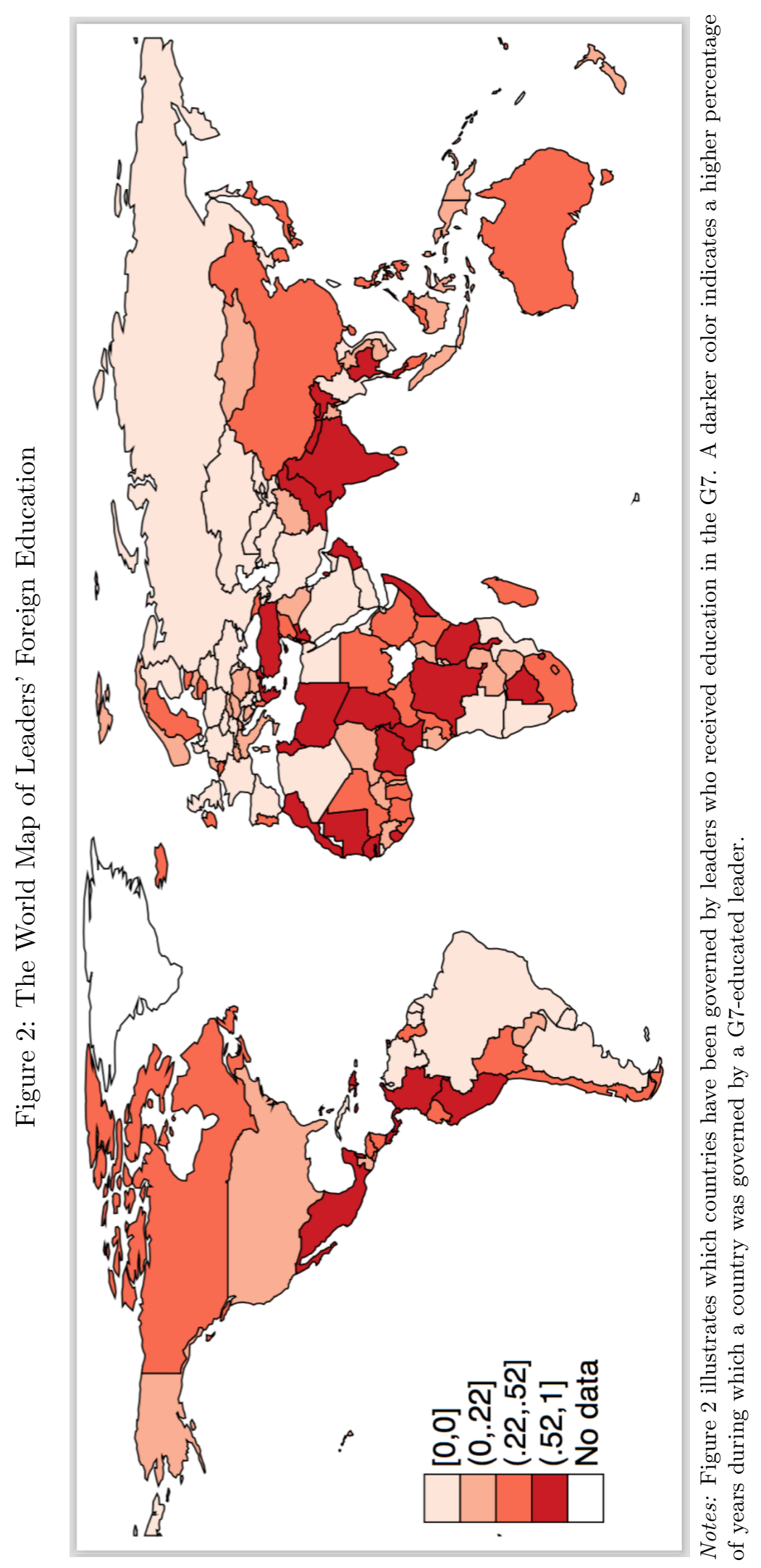


Figure 3: Marginal Effect of U.S.-Education (Percent of Islamic Believers)

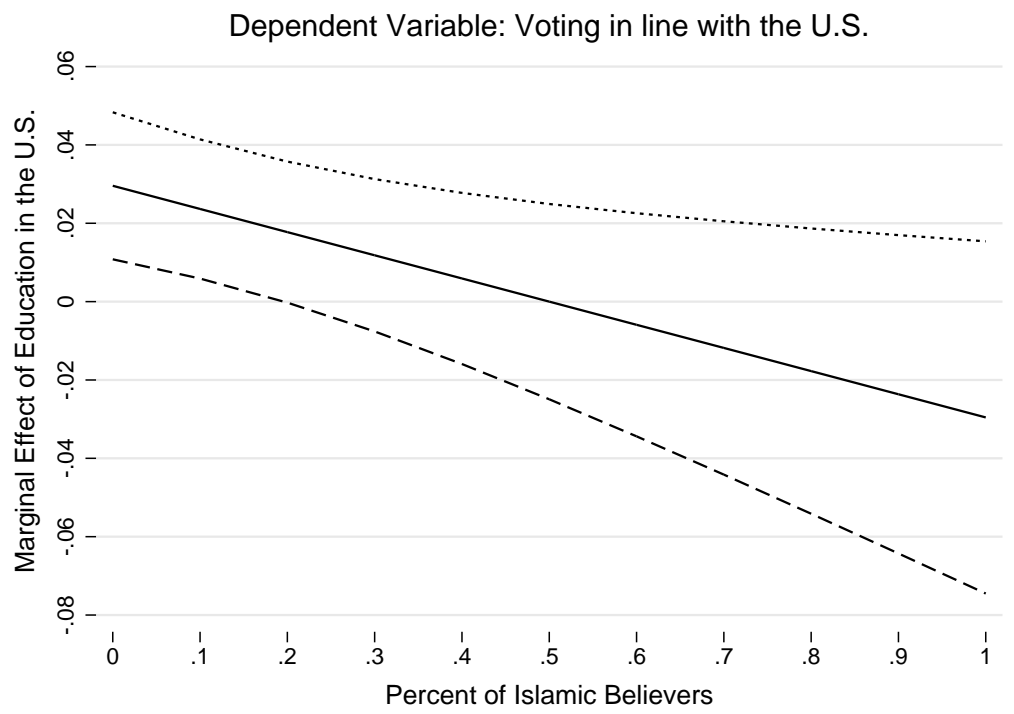

Notes: The figure is based on the regression in column 2 of Table 4 The solid line shows the marginal effect of U.S.-education; the dashed lines represent the 95 percent confidence interval.

Figure 4: Marginal Effect of U.S.-Education (Cultural Distance)

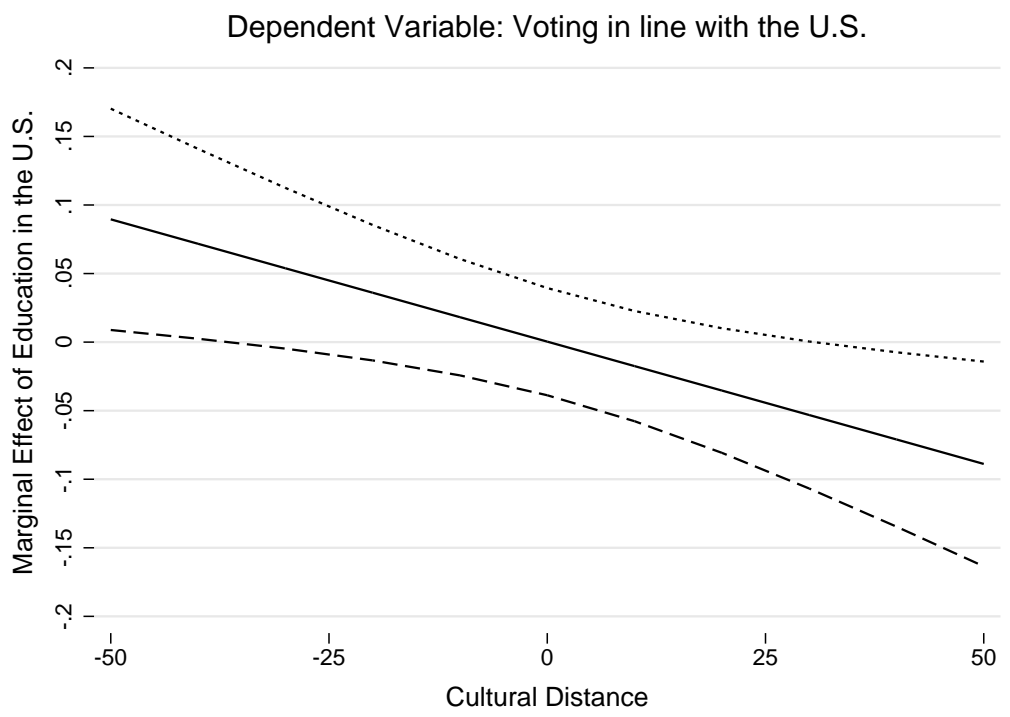

Notes: The figure is based on the regression in column 3 of Table 4 The solid line shows the marginal effect of U.S.-education; the dashed lines represent the 95 percent confidence interval. 
Table 1: Main Results

\begin{tabular}{|c|c|c|c|c|c|}
\hline & $\begin{array}{c}(1) \\
\text { any G7 }\end{array}$ & $\begin{array}{c}(2) \\
\text { country }\end{array}$ & $\begin{array}{c}(3) \\
\text { other G7 }\end{array}$ & $\begin{array}{c}(4) \\
\text { country }\end{array}$ & $\begin{array}{c}(5) \\
\text { other G7 }\end{array}$ \\
\hline Political Color Inline ${ }_{t-1}$ & $\begin{array}{l}0.006^{*} \\
(0.003)\end{array}$ & $\begin{array}{l}0.006^{*} \\
(0.003)\end{array}$ & $\begin{array}{l}0.006^{*} \\
(0.003)\end{array}$ & $\begin{array}{c}0.009^{* * *} \\
(0.003)\end{array}$ & $\begin{array}{c}0.009^{* * *} \\
(0.003)\end{array}$ \\
\hline GDP p.c.t-1 & $\begin{array}{c}0.030 * * * \\
(0.006)\end{array}$ & $\begin{array}{c}0.029 * * * \\
(0.006)\end{array}$ & $\begin{array}{c}0.031^{* * *} \\
(0.006)\end{array}$ & $\begin{array}{c}0.026^{* * *} \\
(0.006)\end{array}$ & $\begin{array}{c}0.026^{* * *} \\
(0.006)\end{array}$ \\
\hline GDP growth gr-1 $_{t}$ & $\begin{array}{c}-0.000^{*} \\
(0.000)\end{array}$ & $\begin{array}{l}-0.000 \\
(0.000)\end{array}$ & $\begin{array}{c}-0.000^{*} \\
(0.000)\end{array}$ & $\begin{array}{c}-0.000^{*} \\
(0.000)\end{array}$ & $\begin{array}{c}-0.000^{*} \\
(0.000)\end{array}$ \\
\hline Imports from $G 7_{j} / \mathrm{GDP}_{t-1}$ & $\begin{array}{c}-0.516^{* * *} \\
(0.104)\end{array}$ & $\begin{array}{c}-0.483^{* * *} \\
(0.099)\end{array}$ & $\begin{array}{c}-0.504^{* * *} \\
(0.101)\end{array}$ & $\begin{array}{c}0.018 \\
(0.021)\end{array}$ & $\begin{array}{c}0.021 \\
(0.021)\end{array}$ \\
\hline Aid from $G 7_{j} / \mathrm{GDP}_{t-1}$ & $\begin{array}{l}-0.161 \\
(0.110)\end{array}$ & $\begin{array}{l}-0.079 \\
(0.107)\end{array}$ & $\begin{array}{l}-0.131 \\
(0.108)\end{array}$ & $\begin{array}{c}0.213^{* * *} \\
(0.048)\end{array}$ & $\begin{array}{c}0.215^{* * *} \\
(0.048)\end{array}$ \\
\hline Education & $\begin{array}{c}0.006^{* * *} \\
(0.002)\end{array}$ & $\begin{array}{c}0.007^{* * *} \\
(0.002)\end{array}$ & $\begin{array}{c}0.004^{* *} \\
(0.002)\end{array}$ & $\begin{array}{c}0.006^{* * *} \\
(0.002)\end{array}$ & $\begin{array}{c}0.006^{* * *} \\
(0.002)\end{array}$ \\
\hline Foreign Education & $\begin{array}{c}0.003 \\
(0.004)\end{array}$ & $\begin{array}{c}-0.041^{* * *} \\
(0.010)\end{array}$ & $\begin{array}{c}0.019 * * * \\
(0.005)\end{array}$ & $\begin{array}{l}-0.030 \\
(0.026)\end{array}$ & $\begin{array}{l}-0.002 \\
(0.007)\end{array}$ \\
\hline Foreign Education*US & & & & $\begin{array}{c}0.044 \\
(0.027)\end{array}$ & $\begin{array}{l}-0.017^{*} \\
(0.009)\end{array}$ \\
\hline Foreign Education*Germany & & & & $\begin{array}{c}0.057^{*} \\
(0.034)\end{array}$ & $\begin{array}{c}0.002 \\
(0.007)\end{array}$ \\
\hline Foreign Education*France & & & & $\begin{array}{c}0.023 \\
(0.026)\end{array}$ & $\begin{array}{c}0.010 \\
(0.008)\end{array}$ \\
\hline Foreign Education*UK & & & & $\begin{array}{c}0.016 \\
(0.026)\end{array}$ & $\begin{array}{l}0.013^{*} \\
(0.008)\end{array}$ \\
\hline Foreign Education*Italy & & & & $\begin{array}{c}0.075^{* *} \\
(0.031)\end{array}$ & $\begin{array}{c}0.004 \\
(0.007)\end{array}$ \\
\hline Foreign Education*Japan & & & & $\begin{array}{c}0.115^{* * *} \\
(0.026)\end{array}$ & $\begin{array}{c}0.006 \\
(0.008)\end{array}$ \\
\hline Host country dummies & No & No & No & Yes & Yes \\
\hline Observations & 28,663 & 28,663 & 28,663 & 28,663 & 28,663 \\
\hline $\operatorname{adj} R-s q$ & 0.46 & 0.46 & 0.46 & 0.70 & 0.70 \\
\hline
\end{tabular}

Standard errors clustered at the country pair level in parentheses.

All models include home country dummies and year dummies.

*** $\mathrm{p}<0.01,{ }^{* *} \mathrm{p}<0.05,{ }^{*} \mathrm{p}<0.1$ 


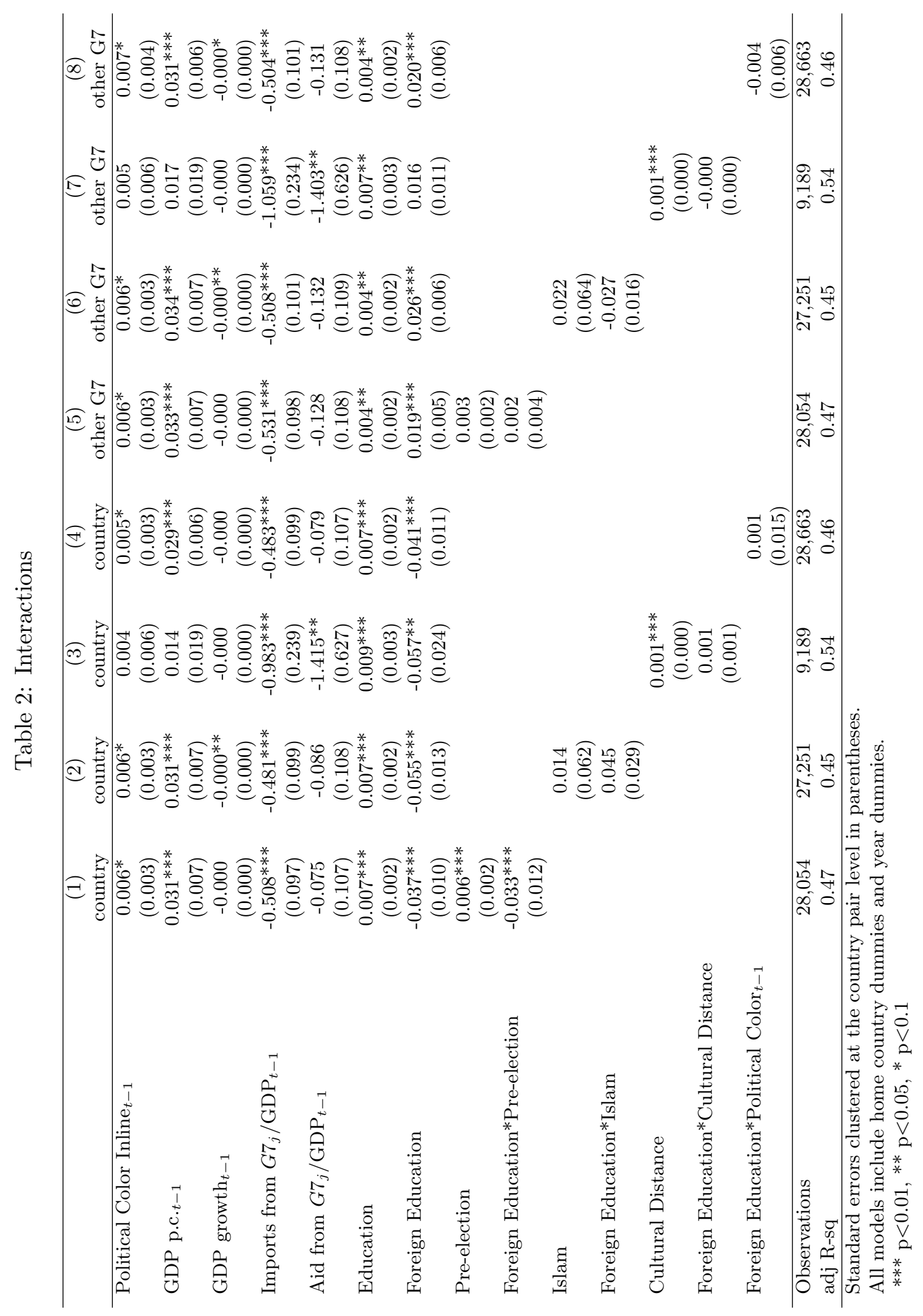


Table 3: Individual G7 Countries

\begin{tabular}{lccccccc}
\hline & $(1)$ & $(2)$ & $(3)$ & $(4)$ & $(5)$ & $(6)$ & $(7)$ \\
& USA & GBR & FRA & DEU & ITA & CAN & JPN \\
\hline Political Color Inline $t-1$ & 0.010 & 0.001 & $0.012^{* *}$ & $0.011^{*}$ & 0.012 & 0.007 & -0.004 \\
& $(0.007)$ & $(0.007)$ & $(0.006)$ & $(0.006)$ & $(0.007)$ & $(0.005)$ & $(0.007)$ \\
GDP p.c. $t-1$ & 0.003 & $0.032^{* *}$ & $0.033^{* *}$ & $0.032^{* *}$ & $0.028^{* *}$ & $0.034^{* *}$ & 0.021 \\
& $(0.014)$ & $(0.014)$ & $(0.013)$ & $(0.014)$ & $(0.014)$ & $(0.014)$ & $(0.013)$ \\
GDP growth $t-1$ & -0.000 & -0.000 & -0.000 & -0.000 & -0.000 & -0.000 & -0.000 \\
& $(0.000)$ & $(0.000)$ & $(0.000)$ & $(0.000)$ & $(0.000)$ & $(0.000)$ & $(0.000)$ \\
Imports from $G 7_{j} / \mathrm{GDP}_{t-1}$ & -0.042 & -0.154 & $0.289^{*}$ & 0.073 & 0.419 & -0.489 & $0.170^{* *}$ \\
& $(0.035)$ & $(0.170)$ & $(0.171)$ & $(0.088)$ & $(0.310)$ & $(0.433)$ & $(0.077)$ \\
Aid from $G 7_{j} / \mathrm{GDP}_{t-1}$ & 0.049 & $0.232^{* *}$ & $0.505^{* * *}$ & 0.267 & $0.224^{* *}$ & $0.552^{*}$ & $0.664^{* * *}$ \\
& $(0.125)$ & $(0.115)$ & $(0.110)$ & $(0.164)$ & $(0.095)$ & $(0.302)$ & $(0.170)$ \\
Education & 0.006 & $0.007^{*}$ & $0.007^{*}$ & $0.006^{*}$ & $0.006^{*}$ & 0.005 & $0.006^{* *}$ \\
Foreign Education & $(0.004)$ & $(0.004)$ & $(0.004)$ & $(0.003)$ & $(0.003)$ & $(0.004)$ & $(0.003)$ \\
& $0.017^{*}$ & -0.008 & -0.012 & $0.041^{* * *}$ & $0.077^{* *}$ & -0.018 & $0.037^{* * *}$ \\
& $(0.009)$ & $(0.009)$ & $(0.013)$ & $(0.005)$ & $(0.033)$ & $(0.017)$ & $(0.013)$ \\
\hline Observations & 4,117 & 4,117 & 3,957 & 4,118 & 4,118 & 4,118 & 4,118 \\
adj R-sq & 0.76 & 0.72 & 0.70 & 0.71 & 0.69 & 0.75 & 0.71 \\
\hline
\end{tabular}

Standard errors clustered at the country level in parentheses.

All models include home country dummies and year dummies.

*** $\mathrm{p}<0.01,{ }^{* *} \mathrm{p}<0.05,{ }^{*} \mathrm{p}<0.1$ 
Table 4: USA, Interactions

\begin{tabular}{|c|c|c|c|c|c|}
\hline & (1) & $(2)$ & (3) & (4) & $(5)$ \\
\hline \multirow[t]{2}{*}{ Political Color Inline $t-1$} & 0.010 & $0.013^{*}$ & 0.007 & 0.012 & $0.015^{*}$ \\
\hline & $(0.007)$ & $(0.008)$ & $(0.016)$ & $(0.008)$ & $(0.009)$ \\
\hline \multirow{2}{*}{ GDP p.c.t-1 } & 0.003 & 0.003 & 0.017 & 0.003 & 0.003 \\
\hline & $(0.014)$ & $(0.015)$ & $(0.050)$ & $(0.014)$ & $(0.015)$ \\
\hline \multirow{2}{*}{ GDP growth gr-1 $_{t}$} & -0.000 & -0.000 & -0.001 & -0.000 & -0.000 \\
\hline & $(0.000)$ & $(0.000)$ & $(0.001)$ & $(0.000)$ & $(0.000)$ \\
\hline \multirow{2}{*}{ Imports from $G 7_{j} / \mathrm{GDP}_{t-1}$} & -0.051 & -0.047 & -0.366 & -0.040 & -0.056 \\
\hline & $(0.037)$ & $(0.038)$ & $(0.239)$ & $(0.035)$ & $(0.040)$ \\
\hline \multirow{2}{*}{ Aid from $G 7_{j} / \mathrm{GDP}_{t-1}$} & 0.069 & 0.058 & 0.375 & 0.049 & 0.076 \\
\hline & $(0.128)$ & $(0.130)$ & $(0.483)$ & $(0.125)$ & $(0.134)$ \\
\hline \multirow[t]{2}{*}{ Education } & 0.006 & 0.006 & 0.011 & 0.006 & 0.005 \\
\hline & $(0.004)$ & $(0.004)$ & $(0.009)$ & $(0.004)$ & $(0.004)$ \\
\hline \multirow[t]{2}{*}{ Education in US } & $0.018^{*}$ & $0.030^{* * *}$ & -0.001 & $0.019 *$ & $0.037^{* * *}$ \\
\hline & $(0.010)$ & $(0.010)$ & $(0.020)$ & $(0.010)$ & $(0.011)$ \\
\hline \multirow[t]{2}{*}{ Pre-election } & $0.008^{*}$ & & & & 0.006 \\
\hline & $(0.004)$ & & & & $(0.004)$ \\
\hline \multirow[t]{2}{*}{ US Education*Pre-election } & $-0.019 *$ & & & & $-0.021^{*}$ \\
\hline & $(0.011)$ & & & & $(0.011)$ \\
\hline \multirow[t]{2}{*}{ Islam } & & 0.130 & & & 0.135 \\
\hline & & $(0.152)$ & & & $(0.153)$ \\
\hline \multirow[t]{2}{*}{ US Education*Islam } & & $-0.059^{* *}$ & & & $-0.066^{* * *}$ \\
\hline & & $(0.024)$ & & & $(0.024)$ \\
\hline \multirow[t]{2}{*}{ Cultural Distance } & & & -0.003 & & \\
\hline & & & $(0.002)$ & & \\
\hline \multirow[t]{2}{*}{ US Education*Cultural Distance } & & & $-0.002^{* *}$ & & \\
\hline & & & $(0.001)$ & & \\
\hline \multirow[t]{2}{*}{ US Education*Political Color } & & & & -0.012 & -0.015 \\
\hline & & & & $(0.015)$ & $(0.015)$ \\
\hline Observations & 4,030 & 3,916 & 1,307 & 4,117 & 3,838 \\
\hline adj R-sq & 0.76 & 0.76 & 0.76 & 0.76 & 0.76 \\
\hline
\end{tabular}

Standard errors clustered at the country level in parentheses.

All models include home country dummies and year dummies.

*** $\mathrm{p}<0.01,{ }^{* *} \mathrm{p}<0.05, * \mathrm{p}<0.1$ 
Table 5: USA, Studies in other G7 country, Interactions

\begin{tabular}{|c|c|c|c|c|c|}
\hline & (1) & $(2)$ & (3) & (4) & (5) \\
\hline \multirow[t]{2}{*}{ Political Color Inline $_{t-1}$} & 0.010 & 0.013 & 0.006 & 0.010 & 0.012 \\
\hline & $(0.007)$ & $(0.008)$ & $(0.014)$ & $(0.008)$ & $(0.009)$ \\
\hline \multirow[t]{2}{*}{ GDP p.c.t-1 } & 0.001 & 0.000 & 0.013 & 0.001 & 0.000 \\
\hline & $(0.014)$ & $(0.015)$ & $(0.046)$ & $(0.014)$ & $(0.015)$ \\
\hline \multirow{2}{*}{ GDP growth gr-1 $_{t}$} & -0.000 & -0.000 & -0.001 & -0.000 & -0.000 \\
\hline & $(0.000)$ & $(0.000)$ & $(0.001)$ & $(0.000)$ & $(0.000)$ \\
\hline \multirow{2}{*}{ Imports from $G 7_{j} / \mathrm{GDP}_{t-1}$} & -0.039 & -0.027 & -0.334 & -0.030 & -0.035 \\
\hline & $(0.038)$ & $(0.039)$ & $(0.239)$ & $(0.037)$ & $(0.040)$ \\
\hline \multirow[t]{2}{*}{ Aid from $G 7_{j} / \mathrm{GDP}_{t-1}$} & 0.087 & 0.071 & 0.407 & 0.065 & 0.090 \\
\hline & $(0.127)$ & $(0.130)$ & $(0.477)$ & $(0.124)$ & $(0.133)$ \\
\hline \multirow[t]{2}{*}{ Education } & $0.008^{* *}$ & $0.008^{*}$ & 0.011 & $0.008^{* *}$ & $0.008^{*}$ \\
\hline & $(0.004)$ & $(0.004)$ & $(0.009)$ & $(0.004)$ & $(0.004)$ \\
\hline \multirow[t]{2}{*}{ Education in other G7 } & $-0.019^{* *}$ & $-0.029 * *$ & -0.024 & $-0.019^{* *}$ & $-0.029^{* *}$ \\
\hline & $(0.009)$ & $(0.012)$ & $(0.022)$ & $(0.009)$ & $(0.012)$ \\
\hline \multirow[t]{2}{*}{ Pre-election } & 0.005 & & & & 0.002 \\
\hline & $(0.004)$ & & & & $(0.004)$ \\
\hline \multirow[t]{2}{*}{ Other G7 Education*Pre-election } & -0.003 & & & & -0.001 \\
\hline & $(0.010)$ & & & & $(0.010)$ \\
\hline \multirow[t]{2}{*}{ Islam } & & 0.116 & & & 0.123 \\
\hline & & $(0.152)$ & & & $(0.153)$ \\
\hline \multirow[t]{2}{*}{ Other G7 Education*Islam } & & 0.031 & & & 0.030 \\
\hline & & $(0.025)$ & & & $(0.024)$ \\
\hline \multirow[t]{2}{*}{ Cultural Distance } & & & $-0.004^{*}$ & & \\
\hline & & & $(0.002)$ & & \\
\hline \multirow[t]{2}{*}{ Other G7 Education*Cultural Distance } & & & $0.003^{* *}$ & & \\
\hline & & & $(0.001)$ & & \\
\hline \multirow[t]{2}{*}{ Other G7 Education*Political Color } & & & & -0.002 & 0.003 \\
\hline & & & & $(0.011)$ & $(0.012)$ \\
\hline Observations & 4,030 & 3,916 & 1,307 & 4,117 & 3,838 \\
\hline adj R-sq & 0.76 & 0.76 & 0.76 & 0.76 & 0.76 \\
\hline
\end{tabular}

Standard errors clustered at the country level in parentheses.

All models include home country dummies and year dummies.

*** $\mathrm{p}<0.01, * * \mathrm{p}<0.05, * \mathrm{p}<0.1$ 
Table 6: Pre-trends

\begin{tabular}{|c|c|c|c|c|}
\hline & $\begin{array}{c}(1) \\
\text { country }\end{array}$ & $\begin{array}{c}(2) \\
\text { country }\end{array}$ & $\begin{array}{c}(3) \\
\text { USA }\end{array}$ & $\begin{array}{c}(4) \\
\text { USA }\end{array}$ \\
\hline Political Color Inline & $\begin{array}{c}0.006^{* *} \\
(0.003)\end{array}$ & $\begin{array}{l}0.006^{*} \\
(0.003)\end{array}$ & $\begin{array}{c}0.010 \\
(0.007)\end{array}$ & $\begin{array}{c}0.012 \\
(0.008)\end{array}$ \\
\hline GDP p.c.t-1 & $\begin{array}{c}0.032^{* * *} \\
(0.007)\end{array}$ & $\begin{array}{c}0.033^{* * *} \\
(0.007)\end{array}$ & $\begin{array}{c}0.002 \\
(0.014)\end{array}$ & $\begin{array}{c}0.002 \\
(0.015)\end{array}$ \\
\hline GDP growth gr-1 $_{t}$ & $\begin{array}{l}-0.000 \\
(0.000)\end{array}$ & $\begin{array}{l}-0.000 \\
(0.000)\end{array}$ & $\begin{array}{l}-0.000 \\
(0.000)\end{array}$ & $\begin{array}{l}-0.000 \\
(0.000)\end{array}$ \\
\hline Imports from $G 7_{j} / \mathrm{GDP}_{t-1}$ & $\begin{array}{c}-0.527^{* * *} \\
(0.093)\end{array}$ & $\begin{array}{c}-0.529^{* * *} \\
(0.094)\end{array}$ & $\begin{array}{l}-0.058 \\
(0.037)\end{array}$ & $\begin{array}{l}-0.058 \\
(0.037)\end{array}$ \\
\hline Aid from $G 7_{j} / \mathrm{GDP}_{t-1}$ & $\begin{array}{l}-0.055 \\
(0.108)\end{array}$ & $\begin{array}{c}-0.051 \\
(0.111)\end{array}$ & $\begin{array}{c}0.084 \\
(0.137)\end{array}$ & $\begin{array}{c}0.083 \\
(0.144)\end{array}$ \\
\hline Education & $\begin{array}{c}0.007^{* * *} \\
(0.002)\end{array}$ & $\begin{array}{c}0.007 * * * \\
(0.002)\end{array}$ & $\begin{array}{c}0.006 \\
(0.004)\end{array}$ & $\begin{array}{c}0.005 \\
(0.004)\end{array}$ \\
\hline Foreign Education & $\begin{array}{c}-0.034^{* * *} \\
(0.011)\end{array}$ & $\begin{array}{c}-0.033^{* * *} \\
(0.011)\end{array}$ & $\begin{array}{l}0.019^{*} \\
(0.010)\end{array}$ & $\begin{array}{c}0.021^{* *} \\
(0.011)\end{array}$ \\
\hline Pre-election & $\begin{array}{c}0.007^{* * *} \\
(0.002)\end{array}$ & $\begin{array}{c}0.008^{* * *} \\
(0.002)\end{array}$ & $\begin{array}{c}0.010^{* *} \\
(0.004)\end{array}$ & $\begin{array}{l}0.011^{*} \\
(0.006)\end{array}$ \\
\hline Foreign Education*Pre-election & $\begin{array}{c}-0.036^{* * *} \\
(0.013)\end{array}$ & $\begin{array}{c}-0.037^{* *} \\
(0.015)\end{array}$ & $\begin{array}{l}-0.021^{*} \\
(0.012)\end{array}$ & $\begin{array}{l}-0.023^{*} \\
(0.014)\end{array}$ \\
\hline Pre-election $_{t-1}$ & $\begin{array}{c}0.009^{* * *} \\
(0.002)\end{array}$ & $\begin{array}{c}0.012^{* * *} \\
(0.002)\end{array}$ & $\begin{array}{l}0.011^{* *} \\
(0.005)\end{array}$ & $\begin{array}{c}0.015^{* *} \\
(0.006)\end{array}$ \\
\hline Foreign Education*Pre-election ${ }_{t-1}$ & $\begin{array}{c}-0.018 \\
(0.014)\end{array}$ & $\begin{array}{l}-0.015 \\
(0.015)\end{array}$ & $\begin{array}{l}-0.012 \\
(0.013)\end{array}$ & $\begin{array}{l}-0.010 \\
(0.013)\end{array}$ \\
\hline Pre-election $_{t+1}$ & & $\begin{array}{c}0.006^{* * *} \\
(0.002)\end{array}$ & & $\begin{array}{l}0.010^{*} \\
(0.006)\end{array}$ \\
\hline Foreign Education*Pre-election ${ }_{t+1}$ & & $\begin{array}{l}-0.014 \\
(0.015) \\
\end{array}$ & & $\begin{array}{l}-0.010 \\
(0.013) \\
\end{array}$ \\
\hline $\begin{array}{l}\text { Observations } \\
\text { adj R-sq }\end{array}$ & $\begin{array}{c}27,383 \\
0.47\end{array}$ & $\begin{array}{c}26,494 \\
0.47\end{array}$ & $\begin{array}{c}3,934 \\
0.77\end{array}$ & $\begin{array}{c}3,807 \\
0.76\end{array}$ \\
\hline
\end{tabular}

All models include home country dummies and year dummies.

Standard errors clustered at the country (pair) level in parentheses.

Foreign Education is education in the respective G7 country in columns (1)-(2) and in the United States in columns (3)-(4).

*** $\mathrm{p}<0.01,{ }^{*} * \mathrm{p}<0.05,{ }^{*} \mathrm{p}<0.1$ 
Table 7: Controlling for Average G7 voting

\begin{tabular}{|c|c|c|c|c|c|}
\hline & $\begin{array}{c}(1) \\
\text { country }\end{array}$ & $\begin{array}{c}(2) \\
\text { USA }\end{array}$ & $\begin{array}{c}(3) \\
\text { USA }\end{array}$ & $\begin{array}{c}(4) \\
\text { USA }\end{array}$ & $\begin{array}{c}(5) \\
\text { USA }\end{array}$ \\
\hline Political Color Inline & $\begin{array}{c}0.004 \\
(0.003)\end{array}$ & $\begin{array}{c}0.016^{* * *} \\
(0.005)\end{array}$ & $\begin{array}{c}0.016^{* * *} \\
(0.005)\end{array}$ & $\begin{array}{c}0.018^{* * *} \\
(0.005)\end{array}$ & $\begin{array}{l}0.018^{* *} \\
(0.009)\end{array}$ \\
\hline GDP p.c.t-1 & $\begin{array}{c}0.014^{* * *} \\
(0.005)\end{array}$ & $\begin{array}{l}-0.022^{*} \\
(0.012)\end{array}$ & $\begin{array}{l}-0.024^{*} \\
(0.013)\end{array}$ & $\begin{array}{c}-0.023^{*} \\
(0.013)\end{array}$ & $\begin{array}{c}0.007 \\
(0.019)\end{array}$ \\
\hline GDP growth $_{t-1}$ & $\begin{array}{l}-0.000 \\
(0.000)\end{array}$ & $\begin{array}{l}-0.000 \\
(0.000)\end{array}$ & $\begin{array}{l}-0.000 \\
(0.000)\end{array}$ & $\begin{array}{l}-0.000 \\
(0.000)\end{array}$ & $\begin{array}{c}-0.001^{* * *} \\
(0.000)\end{array}$ \\
\hline Imports from $G 7_{j} / \mathrm{GDP}_{t-1}$ & $\begin{array}{c}-0.557^{* * *} \\
(0.106)\end{array}$ & $\begin{array}{l}-0.011 \\
(0.033)\end{array}$ & $\begin{array}{l}-0.024 \\
(0.035)\end{array}$ & $\begin{array}{l}-0.014 \\
(0.034)\end{array}$ & $\begin{array}{l}-0.074 \\
(0.141)\end{array}$ \\
\hline Aid from $G 7_{j} / \mathrm{GDP}_{t-1}$ & $\begin{array}{l}-0.192^{*} \\
(0.113)\end{array}$ & $\begin{array}{c}0.004 \\
(0.123)\end{array}$ & $\begin{array}{c}0.005 \\
(0.122)\end{array}$ & $\begin{array}{c}0.032 \\
(0.127)\end{array}$ & $\begin{array}{c}0.170 \\
(0.207)\end{array}$ \\
\hline Education & $\begin{array}{c}0.004^{* * *} \\
(0.001)\end{array}$ & $\begin{array}{c}0.002 \\
(0.002)\end{array}$ & $\begin{array}{c}0.002 \\
(0.002)\end{array}$ & $\begin{array}{c}0.002 \\
(0.002)\end{array}$ & $\begin{array}{l}0.005^{*} \\
(0.003)\end{array}$ \\
\hline Average Other G7 Voting & $\begin{array}{c}0.597^{* * *} \\
(0.030)\end{array}$ & $\begin{array}{c}0.770^{* * *} \\
(0.044)\end{array}$ & $\begin{array}{c}0.777^{* * *} \\
(0.045)\end{array}$ & $\begin{array}{c}0.760^{* * *} \\
(0.045)\end{array}$ & $\begin{array}{c}0.941^{* * *} \\
(0.042)\end{array}$ \\
\hline Foreign Education & $\begin{array}{c}-0.040^{* * *} \\
(0.011)\end{array}$ & $\begin{array}{c}0.005 \\
(0.007)\end{array}$ & $\begin{array}{c}0.007 \\
(0.007)\end{array}$ & $\begin{array}{c}0.012 \\
(0.008)\end{array}$ & $\begin{array}{l}-0.010 \\
(0.009)\end{array}$ \\
\hline Pre-election & $\begin{array}{c}0.004^{* * *} \\
(0.001)\end{array}$ & & $\begin{array}{c}0.005 \\
(0.003)\end{array}$ & & \\
\hline Foreign Education*Pre-election & $\begin{array}{c}-0.035^{* * *} \\
(0.013)\end{array}$ & & $\begin{array}{c}-0.016^{*} \\
(0.009)\end{array}$ & & \\
\hline Islam & & & & $\begin{array}{l}0.129^{*} \\
(0.073)\end{array}$ & \\
\hline US Education*Islam & & & & $\begin{array}{c}-0.023^{*} \\
(0.014)\end{array}$ & \\
\hline Cultural Distance & & & & & $\begin{array}{c}-0.003^{* * * *} \\
(0.001)\end{array}$ \\
\hline US Education*Cultural Distance & & & & & $\begin{array}{c}0.000 \\
(0.000)\end{array}$ \\
\hline Observations & 28,054 & 4,117 & 4,030 & 3,916 & 1,328 \\
\hline adj R-sq & 0.53 & 0.87 & 0.87 & 0.87 & 0.93 \\
\hline
\end{tabular}

Standard errors clustered at the country (pair) level in parentheses.

*** $\mathrm{p}<0.01,{ }^{* *} \mathrm{p}<0.05, * \mathrm{p}<0.1$

All models include home country dummies and year dummies.

Foreign Education is education in the respective G7 country in column (1)

and in the United States in columns (2)-(4). 


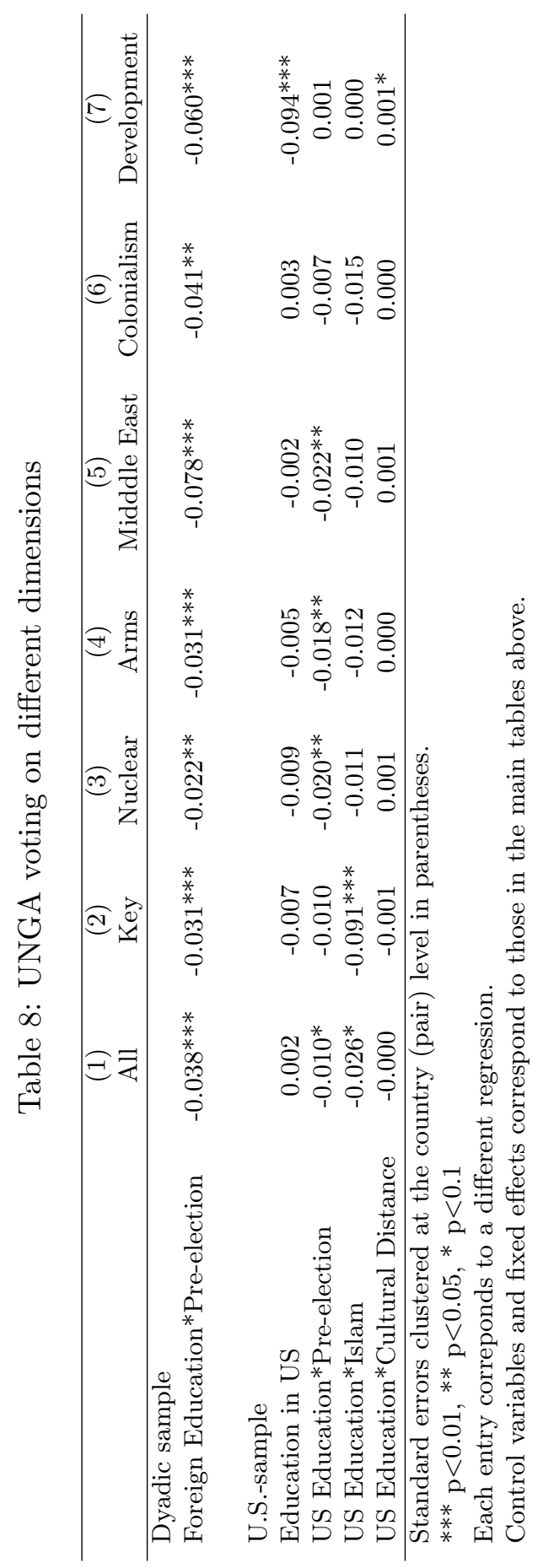




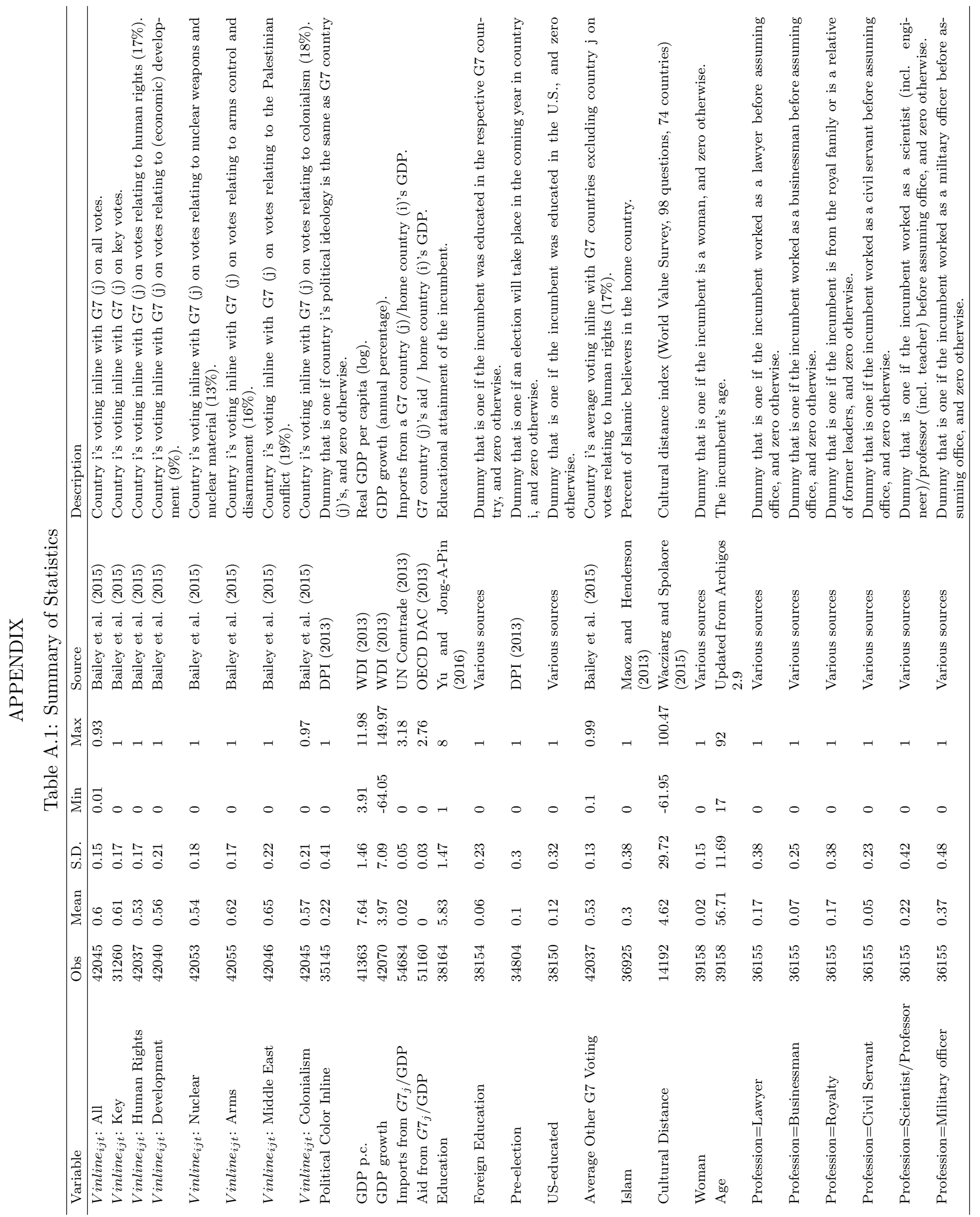




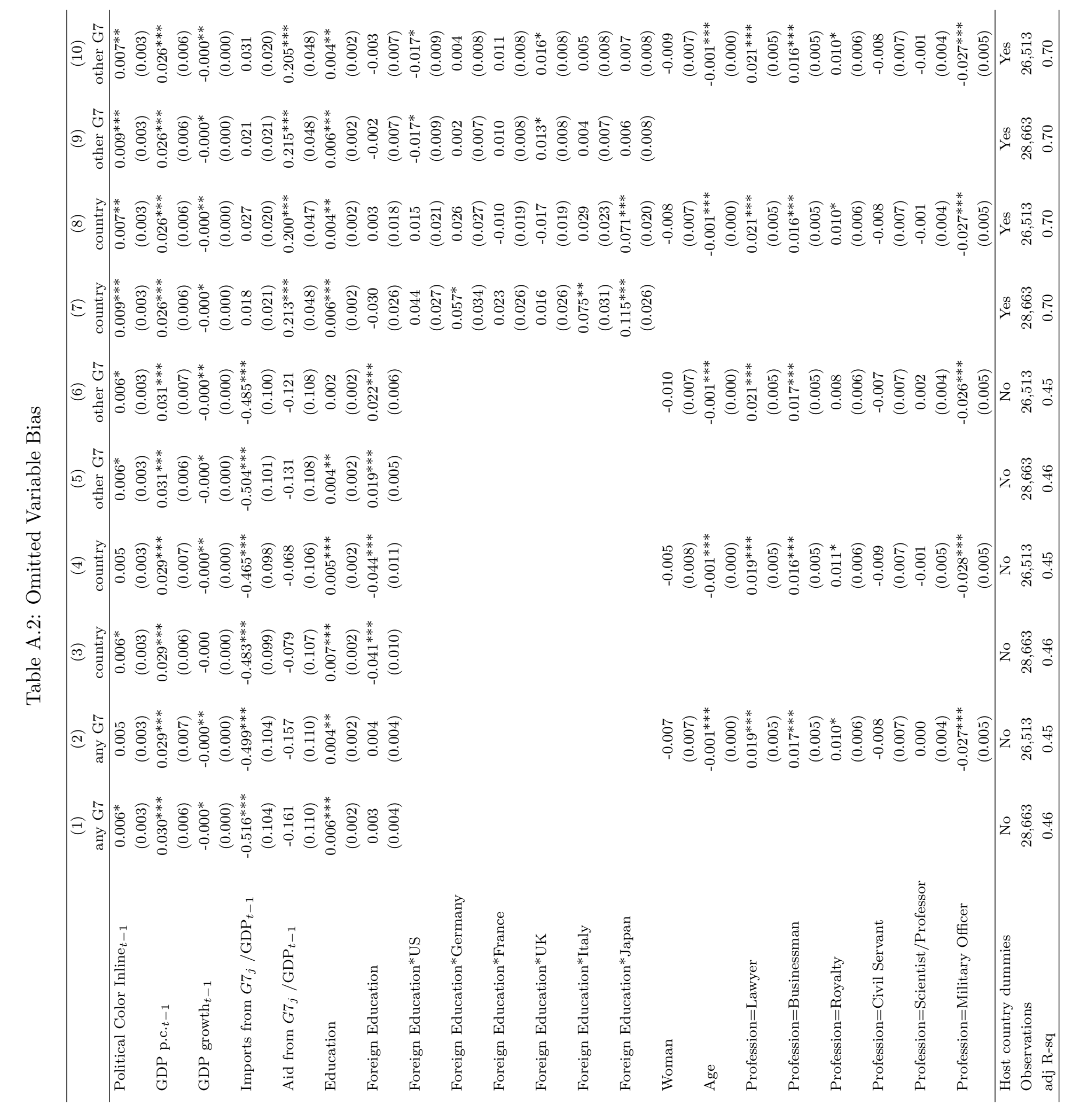




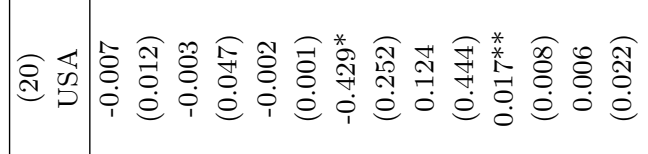

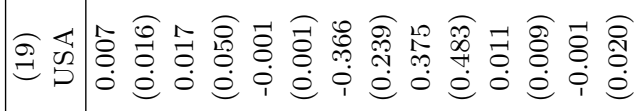

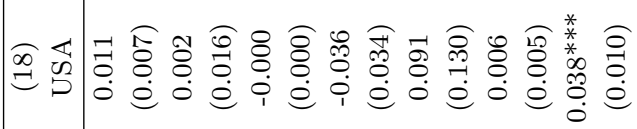

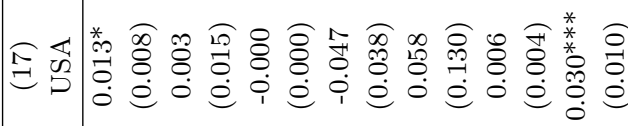

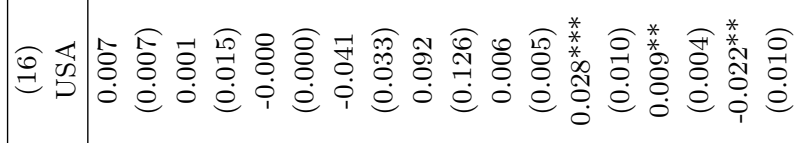

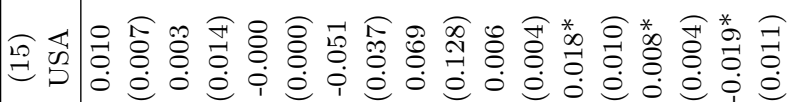

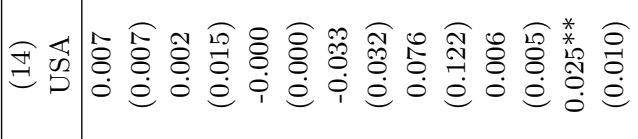

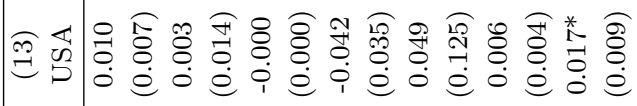

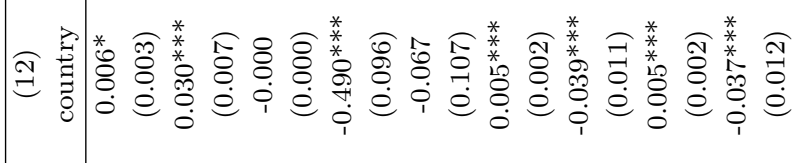

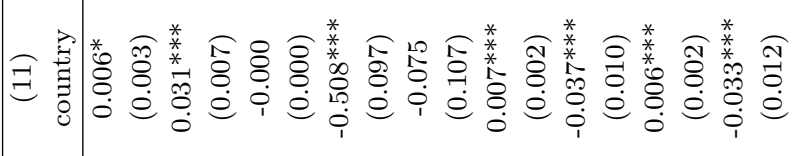

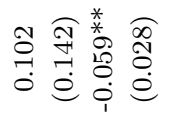

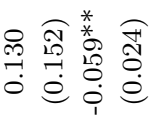

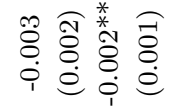

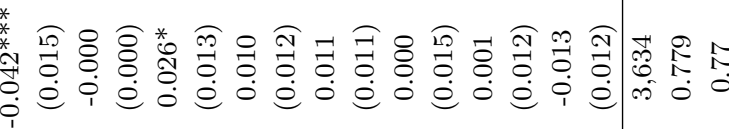

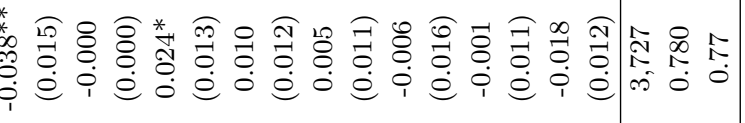

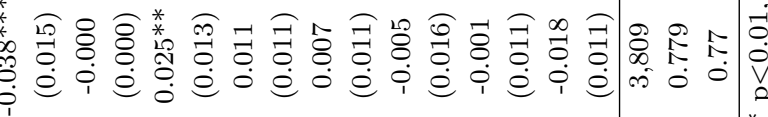

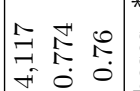

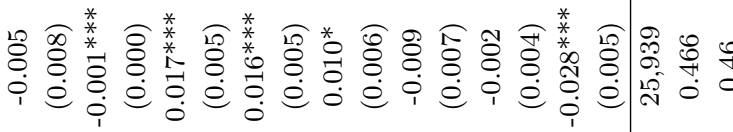

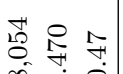

党

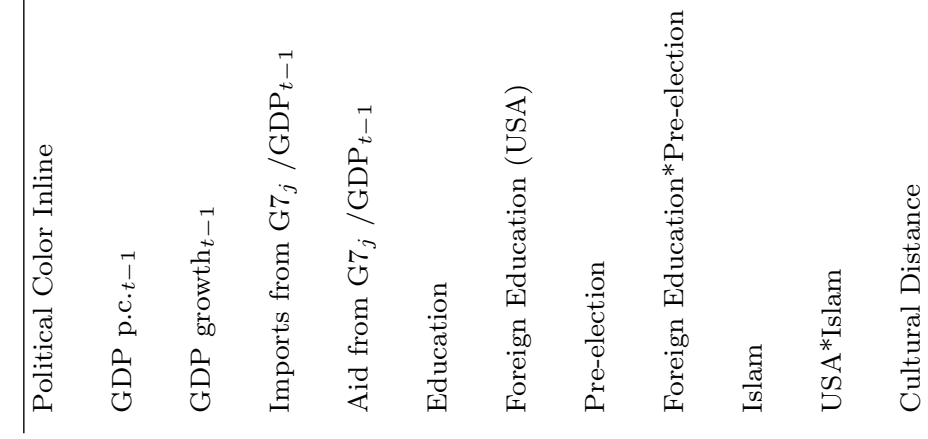

